\title{
Reprisals Remembered: German-Greek Conflict and Car Sales during the Euro Crisis*
}

\author{
Vasiliki Fouka Hans-Joachim Voth
}

First draft: December 2012

This draft: October, 2013

\begin{abstract}
During the Greek debt crisis after 2010, the German government insisted on harsh austerity measures. This led to a rapid cooling of relations between the Greek and German governments. We compile a new index of public acrimony between Germany and Greece based on newspaper reports and internet search terms. This information is combined with historical maps on German war crimes during the occupation between 1941 and 1944. During months of open conflict between German and Greek politicians, German car sales fell markedly more than those of cars from other countries. This was especially true in areas affected by German reprisals during World War II: areas where German troops committed massacres and destroyed entire villages curtailed their purchases of German cars to a greater extent during conflict months than other parts of Greece. We conclude that cultural aversion was a key determinant of purchasing behavior, and that memories of past conflict can affect economic choices in a time-varying fashion. These findings are compatible with behavioral models emphasizing the importance of salience for individual decisionmaking.
\end{abstract}

JEL: D12, D74, F14, N14, N44

Keywords: Consumer boycott, cultural aversion, political conflict, memory, salience, car sales, Euro crisis, German-Greek relations.

*We thank Alexander Apostolides, Jordi Galí, Yannis Ioannides, Tim Leunig, Stelios Michalopoulos, Luigi Pascali, and Giacomo Ponzetto for helpful suggestions. Seminar participants at CREI, UPF, at the EREH-London conference, and at the 12th Conference on Research on Economic Theory and Econometrics in Naxos provides useful advice. The Hellenic Statistical Authority kindly provided car registration data. Voth thanks the ERC for funding through an AdG grant. 


\section{Introduction}

When German Chancellor Angela Merkel visited Athens in 2012, she was greeted by demonstrators waving placards depicting her in Nazi uniform; protesters were denouncing the alleged rise of a "Fourth Reich". During the period 2010-12, the German and the Greek governments clashed repeatedly and in public over the terms of EU bailout packages. Greeks blamed German politicians for harsh austerity measures; officials from Germany made disparaging remarks about the country. The popular press in both Germany and Greece printed incendiary headlines and insulting images. Greek consumer groups called for a boycott of German goods. Strikingly, memories of World War II played an important role in Greek condemnations of German attitudes and policies: German institutions were defaced with swastikas; politicians suddenly demanded reparations for German war crimes committed a half-century earlier; and newspapers both foreign and Greek recounted massacres during the German occupation.

In this paper, we examine how German-Greek animosity affected consumer behavior - and how these events interacted with memories of earlier conflict. In particular, we test if areas in Greece that suffered German reprisals during World War II saw sharper changes in purchasing patterns than other parts of the country. We focus on car purchases because cars are an archetypal German product! Examining car purchases also constitutes a demanding test - for the average consumer, they represent a major (and rare) investment, which makes it less likely that political feelings and the desire to make a public statement influence consumer behavior.

We first compile an index of German-Greek political clashes based on newspaper reports in Greece and on the frequency of internet search terms. These indicators show an explosion of conflict after 2010, with three separate periods affecting a total of six

\footnotetext{
${ }^{1}$ Some care manufactures use highly idiomatic and hard-to-pronounce German slogans in their advertising abroad to polish their German credentials (for exampe, Audi used "Vorsprung durch Technik" in English-speaking countries).
} 
months characterized by particularly intense public conflict. Sales of German-made cars suffered marked declines during these clashes. We combine this time-series information with detailed geographical data on the location of German massacres during the occupation, 1941-44. Following an upsurge in partisan activity, the German occupying forces adopted a policy of harsh reprisals. These involved burning whole villages, and killing the entire (male) civilian population in the vicinity of attacks (Mazower, 1995). To measure the severity of these attacks at the local level, we use lists drawn up by the Greek government designating localities as "martyred towns". These are based on a set of criteria including the percentage of homes destroyed, as well as the loss of human life. The locations of these martyred towns are then matched to prefecture-level car registration data.

We find strong evidence that public conflict and calls for a boycott of German products reduced sales of German automobiles in general; strikingly, these reductions were greater where the Wehrmacht had destroyed entire villages, committing large-scale massacres. Figure 1 shows the distribution of changes in the market share of German cars, during months of conflict and for tranquil periods, for prefectures with a large share of population affected by atrocities during World War II and the rest. The upper panel shows that in months without prominent clashes, changes in the market share of German-made automobiles were indistinguishable between prefectures with many and relatively few massacres. This changes drastically in times of conflict - now the entire distribution is shifted to the left for prefectures that were suffered heavy German reprisals. The effect is large and significant, as we show in the main empirical section below - the difference-in-differences estimate of the effect of a conflict month on the German car market share in areas of Greece with a history of German war crimes is 3.8 percentage points. These findings suggest that consumer behavior - the purchase of big-ticket items like cars - responds strongly to general public sentiment; where local memories of earlier German atrocities could easily be activated by current events, purchases were curtailed sharply. 
Boycotts are frequently used to articulate political views, but their effectiveness is doubtful. More than half of top brands in the US were targeted by a call for a boycott in the period 1980-2000. Nonetheless, there is only limited evidence that consumer behavior is directly influenced by calls for political action.2 For example, boycotts of French wine after the country's failure to support the US in Iraq were probably ineffective (Ashenfelter et al., 2007) $]^{3}$ Teoh et al. (1999) examine the effect of the South African Boycott on the stock prices of affected firms, and find that it had no clear impact. In general, the valuations of firms affected by boycotts do not react Koku et al., 1997). The only counter-examples include a decline in tourist visits by Americans to France after 2003 (Michaels and Zhi, 2010); lower French car sales in China during the 2008 Olympics (Hong et al., 2011); and suggestive evidence that French-sounding products saw their sales slump in the aftermath of the Iraq war (Pandya and Venkatesan, 2012). The paper that is closest in spirit to ours is Fisman et al. (2012). They examine changes in stock market values of Chinese and Japanese firms after a cooling of SinoJapanese relations in 2005 and 2010. This followed the introduction of new Japanese textbooks that downplayed events during the Japanese invasion of China in the 1930s such as the infamous "Rape of Nanking". Stock prices fell more for firms that had a higher sales exposure in terms of foreign sales; effects are strongest in industries with major public sector involvement. At the same time, there appears to be no effect on the stock prices of firms in consumer goods sectors. What is currently missing in the literature is clear evidence that politically-motivated conflict directly influences consumer behavior, and that location-specific interpretations of the past modify these responses.

Our paper also contributes to an emerging literature on the importance of cultural

\footnotetext{
${ }^{2}$ Sen et al. (2001) and John and Klein (2003) argue that free-rider problems make it highly unlikely for boycotts to succeed.

3 Chavis and Leslie $(2006)$ earlier concluded that French wine sales in the US suffered after the start of the Iraq war.
} 
factors in economic and social behavior. Countries that fought numerous wars in the past continue to trade less with each other to the present day, and they engage in less FDI (Guiso et al., 2009). Fertility behavior of immigrants' children is still influenced by their parents' country of origin (Fernández and Fogli, 2006), language characteristics are associated with savings behavior (Chen, 2013), and inherited trust can influence national growth rates (Algan and Cahuc, 2010). Many attitudes persist over long periods: Italian cities that were self-governing in the Middle Ages are richer and more civic-minded today (Guiso et al., 2007), areas of Africa affected by 19C slave-hunts have lower trust in the present (Nunn and Wantchekon, 2011), and German cities that persecuted their Jews during the Black Death were markedly more anti-Semitic in the 1920s and 1930s (Voigtländer and Voth, 2012).

At the same time, culture is not only persistent, it can also change quickly: Attitudes towards pre-marital sex have been transformed in the last century (FernándezVillaverde et al., 2011); Islam changed from an open and tolerant religion to a relatively intolerant one (Chaney, 2008); Franco-German conflict in the last 200 years was repeated and seemingly deeply rooted in cultural differences (Mann, 1916), but has vanished in the last 50 years. One of the key challenges for cultural economics is to analyse the conditions for persistence, and the context in which contemporary attitudes are no longer influenced by the past.

Our work also relates to a growing literature in psychology and economics that focuses on the role of memory as a cause of behavioral biases. Mullainathan (2002) presents a model in which memory limitations can explain a host of phenomena, from stock market volatility to consumption patterns. Kahneman and Tversky (1982) show that remembered events are typically regarded as more representative and more likely. (Gennaioli and Shleifer, 2010) show how "what comes to mind" can shape decisionmaking and lead to distorted decisions. Similarly, emotions (Kahneman, 2011) and fairness considerations (Fehr and Gächter, 2000) can also affect economic decisionmaking, especially when experiences related to the economic decision at hand have left 
individuals a strong emotional impression in the past.

Relative to the existing literature, we make the following contribution: First, we are among the first to show that consumer behavior reacts to political events, in a way that is consistent with time-varying cultural aversion 4 Second, during the Greek debt crisis, "reasons to hate" mattered more in periods of general conflict; the harshness of the remembered past influenced cross-sectional differences in the response to political events. Third, our paper demonstrates that purchases of big-ticket items (like cars) can be affected by political conflict and calls for boycott.

We proceed as follows. Section 2 describes the history and background of GermanGreek conflict since 1941, and it introduces our data sources. Section 3 summarizes the main results; section 4 presents robustness checks and extensions. Section 5 concludes.

\section{Historical Background and Data Description}

In this section, we briefly summarize the history of German-Greek conflict during World War II, as well as the period of crisis after the outbreak of the sovereign debt crisis in 2010. We also introduce our data on car registrations, and describe how our measures of news-based conflict and German reprisals are constructed.

\subsection{German retribution measures in Greece during WWII}

Following a six-month Greco-Italian war and a German military campaign that lasted less than a month, Greece was occupied by Axis forces in May 1941. The country was divided into three occupation zones. The largest one was administered by Italy. Germany occupied a smaller part of the territories, but controlled crucial locations including Athens, Thessaloniki and Crete. Bulgaria administered a relatively small part

\footnotetext{
${ }^{4}$ Here, our findings echo those of Michaels and Zhi (2010), Hong et al. (2011), and Pandya and Venkatesan (2012). In contrast, the main effect in Fisman et al. (2012) is that the stock-market valuation of large firms mainly selling to the public sector declined in peirods of conflict.
} 
of the country close to its own borders. From the beginning, the civilian population suffered under the harsh measures of expropriation and plunder that followed the occupation. The German armed forces requisitioned foodstuffs on a vast scale, leading to a major famine during the winter 1941-1942. An estimated 300,000 people died, and the period still survives in Greek collective memory (Hionidou, 2006).

Throughout Eastern Europe, the German armed forces targeted the civilian population in a bid to deal with partisan attacks. Shooting of potentially uninvolved civilians as a reprisal measure in areas of armed resistance was first authorized in April 1941 in Yugoslavia (Mazower, 1995). It was standard practice in anti-partisan operations in Russia. The OKW5 early on laid down precise quotas on how German troops should spread fear and terror throughout occupied territory - 100 civilians were to be shot for each German solider killed in a partisan attack, 50 for each wounded man, etc. Following the capture of Crete - involving heavy losses by the Wehrmacht in the face of determined local and Allied resistance - reprisal measures were also used Nessou, 2009). General Student, the temporary commander of Crete after the German invasion of the island, instructed his forces to "leave aside all formalities and deliberately dispense with special courts", since these were not fit for "murderers and beasts".

The town of Kondomari in Crete was the first to witness a mass execution of civilians by the Germans on Greek soil: 19 people were shot on June 2, 1941, in retaliation for the death of a German officer in the town's vicinity (Meyer, 2002). Both mass shootings and the burning down of villages became common. Until 1944, an estimated 2-3,000 Greek civilians were executed by the German armed forces on Crete alone, and 1,600 (out of a total of 6,500) towns and villages were destroyed (Nessou, 2009, p. 204).

After Italy surrendered to the Allies in September 1943, the Italian-occupied zone of Greece was taken over by German forces. The Italian troops had been notably lax in their attempts to subdue local partisan groups ("andartes"). Following the

\footnotetext{
${ }^{5}$ Oberkommando der Wehrmacht - Central Command of German Armed Forces.
} 
expansion of German-occupied territory, conflict between guerrilla groups (mostly the Communist-led ELAS) and the Wehrmacht intensified. The German forces increasingly used terror tactics against the local population. Partisan attacks were often followed by indiscriminate shootings of civilians and the destruction of every village in a certain radius from the attack. For example, the town of Mousiotitsa in the northwestern part of Greece had 153 of its inhabitants killed, including women and children, on July 25th 1943. Another 15 localities in the area were destroyed by the Germans (Nessou, 2009). The massacre was part of a mopping-up operation in response to the killing of a German officer in the town of Zita. Similarly, the entire male population of the town of Kalavryta in the Peloponnese was shot, along with inhabitants of several neighboring towns (with a total number of 696 dead) after guerrillas abducted and killed soldiers of the 117th Gebirgsjäger Division in October 1943. One of the last massacres of civilians before the end of the occupation occurred in Distomo, near Delphi. In total, 218 people, including infants, were killed by a Waffen-SS unit on June 10th 1944. Post-war reports of the Ministry of Reconstruction estimate that the total number of dead in Greece may have been as high as 30,000 (Doxiadis, 1947).

Memories of Nazi massacres during the occupation are not far from the surface in Greece today. Family members of the victims of Distomo have sued for reparation payments, taking their case to the German courts and to the International Court of Human Rights. Despite the fact that the Constitutional Court in Germany dismissed the case in 2003 , it was recently revived when an Italian court awarded the descendants of the victims a property belonging to a German NGO in Italy. The case reached the International Court in 2012 in the middle of the Greek sovereign crisis, and featured prominently in the Greek press. ${ }^{6}$

Data on towns that suffered reprisal measures by the Wehrmacht during the German

6 "The government in the Hague for Distomo", Kathimerini, 13 January 2011, http://news. kathimerini.gr/4dcgi/_w_articles_politics_2_13/01/2011_428531 
occupation of Greece come from Presidential Decrees no. 2130 (1993), 399 (1998), 99 (2000), 40 (2004) and 140 (2005). These decrees designate a number of municipalities and communes throughout the country as "martyred towns". Localities in this category were determined - by a committee created in 1997 by the Ministry of Internal Affairs and Public Administration - to have suffered material and human losses in the period 1941-1944, and fulfil one of the following criteria:

1. Complete destruction of housing stock by arson, bombings or explosions.

2. Loss of $10 \%$ of the period's total population by individual or mass executions, as well as by other causes, e.g. blind shootings of civilians.

3. Destruction of housing stock that approaches $80 \%$ of the total and loss of population that approaches $10 \%$ of the total, also taking into account the absolute magnitudes of the losses.

This list of locations includes a total of 78 towns, from which we exclude the following: Doxato, Drama, Choristi (under Bulgarian occupation and destroyed by the Bulgarians) and Domeniko, Tsaritsani, Nea Agchialos (destroyed by the Italians). Figure 2 depicts the regional distribution of affected localities. All places on the list of martyred towns suffered due to German reprisals; they were not destroyed by bombing during the war or during the invasion. 54 out of 72 witnessed mass executions of civilians; the rest were burnt to the ground in retaliation for an insurgency attack against German armed forces in the vicinity (Nessou, 2009). Since data on car registrations, our main dependent variable, are not available at a lower level of aggregation than the prefecture, we construct a prefecture-level index of exposure to German reprisals, in the form of the share of the prefecture's total population in 1940 that lived in "martyred" localities.

\subsection{German-Greek relations during the Greek crisis}

The Greek sovereign debt crisis began to unfold in late 2009, when revised budget deficit figures revealed the country's dire financial situation. This lead to successive 
downgrades of its credit rating. Eventually, with debt markets all but closed to the Greek state, an EU bailout became inevitable. From the beginning, the German government was sceptical of a financial rescue for Greece.7 It finally agreed to the bailout in exchange for harsh austerity measures. From the onset of the crisis, Greek public opinion saw Germany as the instigator of foreign-imposed austerity. The reaction was immediate and intense: In February 2010, the Greek Consumers Association called for a boycott on German products - explicitly highlighting the importance of cars - and instructed consumers on how to identify the national origin of a good by its barcode.

Animosity was further aggravated by incendiary articles in the popular press. German newspapers routinely portrayed Greeks as notorious and lazy cheaters living it up at the expense of the German taxpayer 8 A German weekly featured Aphrodite making a rude gesture on the cover page; German populist politicians suggested that Greece should sell some of its islands to repay its debts $!^{9}$ As the Greek economy contracted and unemployment surged amid severe austerity measures, anti-German feelings in Greece deepened. Greek politicians openly referred to the German special envoy as a "military commander". In early 2012, Greek president Karolos Papoulias publicly complained that the entire country was being insulted by the German finance minister Wolfgang Schaeuble. During the 2012 visit of German chancellor Angela Merkel to Athens, thousands of people demonstrated in the streets of Athens.

Much of the criticism of German policy in Greece after 2010 used references to the German occupation during World War II, and employed Nazi-era symbols to protest against the way Greece was being treated. Mentions of war crimes and unpaid German reparations became much more frequent in the press. Former foreign minister Stavros Dimas, addressing the Greek parliament in March 2011, reminded everyone that Greece never waived its right to claim reparations, and that a forced loan taken out by Germany

\footnotetext{
7 "German "no" to facilitating the repayment of the 110 billion euros", Kathimerini, 13/10/2010

8 "Die Griechenland-Pleite", Focus Magazine, Nr. 8, 2010.

9 "Verkauft doch eure Inseln, ihr Pleite-Griechen", Bild, 27/10/2010
} 
during the occupation had not been repaid. ${ }^{10}$ Populist newspapers printed swastikas surrounded by the stars of the European union to symbolize that EU policy was as harsh as Nazi occupation.

An article by the English Daily Telegraph illustrates the way in which past conflict suddenly came to matter for Greeks after the start of the debt crisis. In the issue of February 11, 2012, the Telegraph profiled the life of Eleftherios Basdekis, who spent his "entire life beneath a German cloud". A survivor of the Distomo massacre, he eventually build a successful trucking business, which went bankrupt after the start of the crisis. The article also cited a mother from Distomo saying that she "hated Germany", that Angela Merkel was "a monster", and that the Germans "killed Distomo; they stole our gold; they belittle Greece." A bar owner is quoted as saying "five years ago, no one had any problem with Germany. But now people are getting upset. The Germans say we are lazy, which is not fair".

As the Telegraph article illustrates, hatred of Germans suddenly resurfaced after the outbreak of the debt crisis. In addition, Greeks from towns destroyed after 1941 often interpreted recent acrimony in the light of earlier conflict. Our hypothesis is that the persistence of collective memories of the German occupation is stronger in areas of Greece that actually fell victim to German atrocities, and that the revival of these memories during specific conflict events manifests itself through consumer decisions.

In order to identify months of heightened conflict in German-Greek relations during the euro crisis, we use a measure based on the frequency of newspaper references to political tension between the two countries. Our approach can be illustrated with an example from Lexis-Nexis. Figure 3 shows the frequency of the joint occurrence of the words "anti-German" and "Greece" in articles appearing in international news media. For the years before 2009, the word pair is virtually inexistent. Thereafter, the

10 "The issue of German reparations is open but...", Kathimerini, 28 March 2012, http://www. kathimerini. com . cy/index . php?pageaction=kat\&modid=1\&artid=83628\&show $=\mathrm{Y}$ 
frequency count increases sharply, reaching peaks in 2010 and 2011.

To obtain a measure of perceived German-Greek conflict within Greece, we compute the frequency of conflict-related articles in a leading Greek newspaper, Kathimerini. It is the largest daily newspaper by circulation during the period 2008-2012; its entire archive of articles is digitized and available electronically. Our database consists of a total of 64,854 articles published in the sections on "Greece", "Politics" and "Economy". We compute the monthly share of articles related to German-Greek conflict using an approach similar to Baker et al. (2013). Starting from a human audited sample of articles, this procedure selects the terms that jointly best identify articles referring to German-Greek conflict. The resulting set of terms used to identify the relevant articles is the one that performs closest to the "gold standard" of human readings.

Using this procedure, we classify an article as conflict-related if it contains the stem "german-" and at least one of the words in the set \{memorandum, troika, haircut, Distomo, default, austerity, Schaeuble\}. This gives us a monthly count of conflict-related articles, which we normalize by the total number of articles Kathimerini published in the month. More details on the term-selection algorithm are given in the Data Appendix.

We identify event months as those showing a large jump in the share of articles devoted to German-Greek conflict. This is based on the turning points in the growth rate series; these are defined as local maxima $\left(y_{t}>y_{t-1}\right.$ and $\left.y_{t}>y_{t+1}\right)$ that are larger than one standard deviation. Because of delays between purchasing decisions and car registrations, we define as a conflict event each turning point in the news-based series and the subsequent month month 11 The identified turning points are depicted in Figure 4. Most of them coincide with major episodes in the Greek debt crisis. Table 1 highlights these episodes and offers a brief chronology of German-Greek relations during the crisis.

\footnotetext{
${ }^{11}$ According to Cosumer Service Centers and the Ministry of Transport, a registration can take from 3 days to 2 months, depending on whether the car has already passed through customs at the time of the purchase.
} 


\subsection{Car registrations}

The Greek Ministry of Transport and Communications collects data on registrations of new passenger vehicles. These are disseminated by the Hellenic Statistical Authority (HelStat). We have access to monthly data on the number of new passenger vehicles registered in each prefecture for the period from January 2008 to August 2012, by manufacturing plant.

Aggregate car sales slumped after the start of the financial crisis. Annual unit sales had totalled close to 180,000 before 2007. By 2011, with the Greek economy contracting rapidly, car sales fell to barely 60,000 per annum, a decline by almost two-thirds over four years. Analysing sales trends of cars in Greece is complicated by the fact that German car manufacturers performed strongly over the last decade. World-wide, the share of German brands has been rising. This partly reflects the recovery of Volkswagen sales and the significant decline in Toyota's market share ${ }^{12}$ Figure 5 compares the share of German cars in the Greek car market with that in the European market overall. The overall trend is broadly similar.

The raw data from HelStat does not contain information on the brand of registered vehicles. However, HelStat provides a correspondence list that allows us to match production plants to car manufacturers. This correspondence does not always distinguish between brands produced by the same manufacturer. This is true for the Daimler group, producer of both Smart and Mercedes vehicles, and for the Fiat group, which also produces Alfa Romeo and Lancia. Despite this issue, we are able to distinguish German from non-German brands in our sample; the former include Volkswagen, Opel, Audi, BMW, Porsche and the brands of the Daimler group 13 For our purposes, a car's

\footnotetext{
12 "VW conquers the world", The Economist, 7 July 2012, http://www.economist.com/node/ 21558269

${ }^{13}$ Data on vehicle registrations are available from January 2004 on, but we are unable to distinguish German brands in the earlier sample, due to the fact that Daimler was also owner and producer of Chryslers.
} 
"nationality" is not determined by ultimate ownership of the company, but the place of manufacture of (most) cars - we count Seat as a Spanish car maker despite the fact that it is owned by Volkswagen 14

Summary statistics for the monthly sales of brands in our sample are given in Table 2. Toyota is the firm with the highest average sales number, followed by Opel and Volkswagen. At the opposite end of the spectrum are small luxury car makers such as Ferrari and Maserati, with average sales of only one car per month. To compare like with like, we exclude small manufacturers with less than 10 vehicles sold in the total period 2008-2012.

Many German cars are luxury products. These suffered greater declines in sales as a result of the crisis. To avoid biasing our results upwards, we perform key parts of our empirical analysis for the "Volkswagen category" only. This is composed of a group of manufacturers focusing on compact vehicles, and mid-sized family cars. This category includes the following brands: Volkswagen, Opel, Citroen, Ford, Honda, Hyundai, Nissan, Peugeot, Renault, Seat, Skoda, Toyota. 15

\subsection{Data descriptives, control variables and balancedness}

Our dataset contains information on 51 prefectures over the period January 2008 to August 2012. The main features of the data are summarized in Table 3. Massacres during the German occupation occurred in 21 out of 51 prefectures, equivalent to $41 \%$ of the sample. The share of the (pre-war) population living in towns and villages later destroyed serves as our main explanatory variable. On average, a little more than one percent of Greeks in 1940 were so affected; Fokida, on the Northern shore of the Gulf of Corinth, is the worst-affected prefecture with a share of $12 \%$. The average prefecture

\footnotetext{
${ }^{14}$ To the extent that Seat is actually perceived as German, we will understate the shift away from German cars, biasing our results downwards.

${ }^{15}$ Including other brands in this category (Daewoo, Daihatsu, Isuzu, Kia, Mitsubishi, Subaru, Audi) does not significantly alter the results.
} 
in our sample saw monthly sales of 267 cars during the period; sales were as low as zero in some prefectures, and could reach as many as 16,365 cars per month. The share of German cars sold was on average $28 \%$; especially in the smaller prefectures, the share fluctuates strongly from month to month, and in some cases, it can reach either 0 or 100\%. Finally, we classify six (out of 56) months in our sample as "conflict months".

Our main control variables come from the 2001 Greek Census, the latest one for which data is available at the prefecture level. It includes information on population size, employment in agriculture and industry, the share of civil servants, education, and the unemployment rate. Table 4 compares these variables for prefectures with and without reprisals. Overall, there are few meaningful differences between the two groups - the share of employment in agriculture is similar, as is the proportion of the labor force in industry. The share of civil servants, a group that was hit hard by the crisis, is almost identical. Education levels are also comparable - the largest difference is for the share of citizens with secondary education (19\% in reprisal prefectures, $17 \%$ in the others). Unemployment rates differed by one percentage point, with a baseline of $12 \%$. Unfortunately, few variables are available at an annual frequency for the later years of the sample, in which months of German-Greek conflict are concentrated.

Except for the share of population with secondary education (which is higher in reprisal prefectures) there are no significant differences between reprisal and non-reprisal prefectures. It is more plausible that the location of partisan attacks and subsequent retaliation by German troops was affected by geography. Ruggedness is also correlated with reprisals. More rugged terrain provided cover for the partisans, who had most of their operational bases in the mountains of Central and Northern Greece. Distance from a main road is also (negatively) correlated with reprisals. This reflects the German tactic of punishing villages in the vicinity of a partisan attack, many of which occurred near roads, and bridges. Though roads seem to a be predictor of reprisals, railways are not. Finally, the share of seats that each prefecture allocated to the Communist Party in the 1936 parliamentary elections is very similar between reprisal and non- 
reprisal prefectures. Communist-dominated ELAS was the main guerilla group during the occupation, and its activities might have been more welcome in prefectures that showed more communist support. This could be correlated to both the locations of reprisals and to a general reactionary stance in certain prefectures that persists until today. However, ideological preferences are not correlated with the location of military action. We will control for the above variables in all our empirical specifications.

\section{Empirical analysis}

In this section, we present our main empirical result - the dramatic decline in German car sales during the German-Greek crisis in prefectures affected by World War II massacres, compared with sales in other areas. We first present our results by using simple conditional averages before proceeding to panel regressions. The robustness section shows that our conclusions are not affected if we use alternative measures of GermanGreek conflict, or of the scale of German atrocities. Finally, we show that memories of German war crimes had bigger adverse effects on the market share of German cars in prefectures where the population joined boycott groups on Facebook.

\subsection{Baseline results}

We first establish the extent to which German car sales fell in times of German-Greek political conflict - and how much larger this decline was in areas affected by war crimes committed after 1941. As a first step, we perform a difference-in-differences tabulation

of changes in market shares for German cars, in crisis and non-crisis months, for reprisal and non-reprisal prefectures. To adjust for seasonal effects, we compare the share of German cars in each month with sales 12 months earlier. Table 5 presents the results. In panel A, we analyse the shift for all German brands; in panel B, for the Volkswagen category. In prefectures without reprisals, the gain in market share for German cars was 0.35 percentage points (VW-category: 0.7 ) lower in crisis months than in normal 
times. In contrast, in prefectures that saw German reprisals, the relative decline is much sharper - 3.84 percentage points (6.79 in the VW category). Overall, the difference-indifference estimator suggests an effect of 3.5\% (VW-category: 6.1\%) - a marked shift over a period of a few months.

Next, we establish the differential effect of an event month on the market share of German brands by estimating the following specification:

$$
y_{j t}=\alpha+\lambda_{t}+\beta_{1} C_{t}+\beta_{2} D_{j}+\gamma C_{t} * D_{j}+\mathbf{X}_{j} \delta+\epsilon_{j t}
$$

where $y_{j t}$ is the 12-month difference of the share of vehicles of German manufacturers registered in prefecture $j$ at time $t, \lambda_{t}$ are year fixed effects, $C_{t}$ is a dummy for a conflict month, $D_{j}$ is the share of the prefecture's 1940 population that lived in towns affected by German reprisals, and $\mathbf{X}_{j}$ is a vector of prefecture controls. The empirical model amounts to a difference-in-differences strategy, comparing the share of German brands between prefectures with and without a past history of German reprisals, in months of conflict relative to months without a conflict event. The only difference from classical DID is that the treatment variable $D_{j}$ is not a dummy, but a continuous index proxying for exposure to reprisals. We are principally interested in the sign and magnitude of the interaction coefficient $\gamma$.

Table 6. Panel A reports baseline estimates for all car brands. Columns (1) and (2) restrict the sample to prefectures with and without reprisals respectively. The estimated effect of a conflict month on the German market share is negative in both cases. However, for regions that suffered reprisals, the estimate is almost 8 times larger than for non-reprisal areas. To test if the difference is statistically significant, we interact the conflict month with the measure of massacre intensity. The results in column (3) show that the effect of conflict is systematically and significantly larger in areas that suffered German reprisals. This result is unaffected when we add our set of standard controls. The results are also quantitatively important: the estimated interaction coefficient implies that a one standard deviation increase in the share of 
affected population in reprisal prefectures leads to an additional drop of 4.2 percentage points in the share of German cars.

Column (5) adds interactions of the baseline controls with the conflict month dummy to the regression setup. Since we are not able to control for prefecture observables that vary at a monthly frequency, this approach allows us to proxy for effects of a conflict month that differ among prefectures and depend on observable characteristics other than the share of population affected by reprisals. Adding these interactions does not affect the results: the coefficient of the interaction implies that a standard deviation increase in the share of the population affected by reprisals leads to a drop of 4.3 percentage points in the German car share in conflict months. Column (6) estimates an alternative specification, controlling for prefecture fixed effects and prefecture-year interactions. Including these actually increases the size of the coefficient for the interaction term.

Panel B of Table 6 repeats the exercise for cars in the Volkswagen category. After removing luxury cars from the sample, there is an even larger (differential) drop in the German car share in months of conflict. This is contrary to the intuitive prediction that sales of luxury cars should have slumped more in months when there was, in effect, bad news about the future of the Greek economy. The average difference between reprisal and non-reprisal prefectures for the Volkswagen sample grows to almost 4 percentage points. The implied difference between reprisal and non-reprisal prefectures corresponds to a drop equivalent to $10.7 \%$ of the average market share of German brands in the Volkswagen category in the period 2008-2012. This is an economically large shift, particularly for a durable good and over a short period of time.

The magnitude of the interaction effects is best judged graphically. How high does the share of the population affected by German reprisals have to be for effects to become large and significant? Figure 6 plots the marginal effect of a conflict month for different values of the share of the population living in locations that suffered massacres. As is readily apparent, the implied effect is negative from the start; it becomes significant 
from a share of $3 \%$.

\subsection{Robustness}

In this section, we stratify our dataset by observables in order to examine when the effect we find is most pronounced. We also examine the robustness of our results to using alternative measures of conflict and reprisals.

\subsubsection{Sample stratification}

In Table 7, we examine if our estimated effect of conflict on the German market share is broadly similar when we subdivide the sample according to the structure of employment, education levels, unemployment levels, and a measure of political preferences. Both above and below median subsamples show a drop in the German share and a difference between reprisal and non-reprisal prefectures in most cases. We find stronger and more tightly estimated interaction effects in areas that are less agricultural and more industrial, with lower education, less unemployment in 2011 and a lower increase in unemployment between 2008 and 2011. Areas with more votes for "Golden Dawn" (a neo-Fascist party campaigning on a strongly nationalistic and xenophobic platform) show both a larger drop in the German share and a bigger difference in the drop by reprisal status. We also find stronger, more tightly estimated effects for areas with slower population growth after 1940. Since most of the differences in population growth reflect migration, this suggests that the grip of the past in crisis times is strongest in areas with low in-migration (or net outflows); areas that gained population (as a result of migration from the rest of the country) show no clear interaction effect 16 This is not due to over-representation of reprisal prefectures in the part of the sample with lower population growth: 10 out of 21 reprisal prefectures had an above median change in

\footnotetext{
${ }^{16}$ This finding is similar to the result in (Voigtländer and Voth, 2012), who show that anti-Semitism in Germany persisted strongly in areas with low population growth.
} 
population from 1940 to 2000.

Finally, we examine if areas that supported the Communist Party before 1940 show stronger reactions to German-Greek conflict today. Table 7, column (10) points in this direction, with coefficients being larger in the subsample of prefectures that allocated a seat to the communists in the 1936 parliamentary elections. However, the size of the subsample is small and the interaction coefficient — though smaller in magnitude — is only significantly estimated for prefectures that did not support the Communist party.

\subsubsection{Measures of political conflict}

Next, we examine the robustness of our findings with respect to two alternatives the linearity of the assumed response to news, and the type of news index used. In our baseline specification, we assume that German car sales were affected in a nonlinear fashion by news about the German-Greek conflict. Here, we also examine a linear relationship. Columns (1)-(3) of Table 8 replace the conflict month dummy with the monthly share of conflict-related Kathimerini articles. Column (1) is our baseline specification with a standard set of controls. The share of Kathimerini articles related to German-Greek conflict is negatively correlated with the German car market share and the interaction coefficient is strongly negative and significant. The coefficient for the share of the population affected is positive, but relatively small. Once we add interactions of the controls with the share of articles, we get an interaction coefficient that is larger in magnitude, but less precisely estimated. Significance is lost when we use prefecture fixed effects and prefecture-year interactions, though the coefficient remains negative and of similar size.

Table 8 also examines robustness with respect to using an alternative index of political conflict. The extent to which public reaction precedes or follows the news is debatable. If news outlets cater to the views of their audience, then reporting volume will spike (shortly) after an important event. If, conversely, reporting itself creates the adverse reaction, then the pattern will be reversed. We explore an alternative 
search-based measure of German-Greek conflict that proxies more for the demand-side of news. We use data on web searches from Google Insights for terms related to sources of tension in German-Greek relations during the period 2008-2012. For a given search term, the frequency index provided by Google Insights is a normalization of the share of total searches represented by the term in a given time and region.17 We use this index to construct a measure of public interest in German-Greek related issues, based on the following searches - conducted in the Greek language, in Greece - for the following terms: "Germans", "German reparations" and "Distomo". It is surprising that the vague term "Germans" first appears with a non-zero value in the Google index in February 2010, the very month when the first austerity measures were announced and the consumer boycott started.

For each of the terms above we compile a monthly search index from Google for the period 2008-2012. The value of the index is practically zero until early 2010. Figure 7 plots the growth rate of the index alongside the growth rate of the Kathimerini conflict-related article share. There is substantial overlap between the two. We use the growth rate of the Google index as a continuous measure of conflict in columns (4)-(6) of Table 8. Here, the interaction term is robustly negative across specifications. The effect is more modest than the baseline using newspaper articles - a standard deviation increase in the Google index increases the difference between reprisal and non-reprisal prefectures by 0.5 percentage points. However, the results suggest that independent of the type of indicator for the time-varying intensity of political conflict used, there is strong evidence of a differential effect according to reprisal status on car purchasing.

\footnotetext{
${ }^{17}$ Only terms with hits above a certain threshold are considered for the construction of the index. As a result, the index often takes on the value 0 when the search volume for a term is low.
} 


\subsubsection{Measures of reprisal status}

Table 9 examines the effect of using alternative measures of reprisal status. In the first three columns, we use a simple dummy variable for prefectures that contain at least one town that suffered reprisals during the German occupation. Estimated coefficients suggest that the German market share drops only in reprisal prefectures, with the interaction coefficient in column (1) being significant. When adding interactions of the baseline controls with the conflict month and prefecture-year fixed effects, the coefficient retains its sign, but loses significance.

In columns (4) - (6), we repeat the exercise using a dummy for the top quartile of destroyed towns - in effect comparing the top 25 percent of the sample in terms of population affected by reprisals with the other 75 percent. In this way, only areas with a substantial amount of destruction are counted as affected by German massacres. The results show large and highly significant effects - in all three specifications, the interaction effect is negative, suggesting a collapse in German market share by 9-12 percentage points in reprisal prefectures compared to the rest. Finally, in columns (7)(9) of Table 9, we use an alternative measure of wartime destruction. This is the share of each prefecture's 1940 building stock that was destroyed in the years 1941-1944. It is correlated with the extent of German reprisals, but it is a noisier proxy that also reflects other types of wartime destruction. According to the Subministry of Reconstruction (1946), which provides the data for the construction of this variable, German reprisal

measures were responsible for one fourth of the total number of buildings destroyed. The rest was destroyed by wartime bombing, razed to make space for fortifications, or affected by Bulgarian reprisals in their zone of occupation. We find negative coefficients throughout, but only the baseline specification in column (7) is statistically significant.

\subsection{The potential effect of unobservables}

One of the potential weaknesses of our analysis is the paucity of high-frequency, prefecturelevel control variables. To gauge the potential effect of unobserved variables, we imple- 
ment the method of Altonji et al. (2005) of examining how much the coefficient of our main variable of interest changes when we add control variables - and then ask how big the effect of unobservables on the key variable's coefficient would have to be for results to become insignificant. In the unrestricted regression, we use no controls other than year-fixed- effects; in the first exercise, we include prefecture-level controls as used in our baseline regression specification (Table 6, col 4). Subsequently, and to proxy for the effect of time-varying unobservables, we add to this the interactions of these baseline controls with the confict month.

Table 10 presents the results, for both the full and the Volkswagen sample. For the baseline specification and the full sample, the effect of unobservables would have to be 19 times larger than the effect of the existing control variables (and act to the opposite direction) before the interaction effect between the conflict month and the reprisal prefecture dummy becomes zero. For the VW sample, the ratio is 13 . These very large ratios capture the fact that our estimated coefficient is largely unaffected when we add controls. When extending the baseline set of controls to include interactions with the conflict month, the Altonji ratio in the VW category is 6.7 - again, this implies that only variables that are much stronger than existing controls could reduce the key effect to insignificance.

\subsection{De-friending Germany}

Is the differential effect on German car sales between reprisal and non-reprisal provinces really indicative of anti-German sentiment? To explore this issue further, we turn to the membership of Facebook groups dedicated to boycotting German products. We search for various versions of the phrases "boycott german products", "boycott foreign products" or "boycott Germany", and identify around 40 Facebook groups devoted to this purpose. Using the list of members for open groups, we assemble geo-coded information on members. To this purpose, we use the entry for "current city", for members making this information publicly available. In this way, we collect data on 
1,900 boycott group members. These are then aggregated into a membership count for each prefecture. We normalize this measure by the prefecture's population. The spatial distribution of membership is shown in Figure 8. Prefectures that witnessed major massacres, such as Achaia and Viotia, belong to the highest quartile of the distribution of Facebook boycott groups.

In Table 11, we examine if the interaction between reprisals and political events is stronger in areas where more Greeks joined Facebook boycott groups ${ }^{18}$ We find that the interaction effect is large and significant for all prefectures that have more than the median membership of anti-German boycott groups. In the group of prefectures with below-average membership, only one estimated interaction effect is negative, and the result is non-significant. This pattern suggests that the decline in the market share of German cars - especially in provinces that suffered German reprisals, and in months of conflict - was part of a broader pattern of politically charged animosity. Where people did not join Facebook groups aimed at boycotting German products, contemporary events did not interact with memories of the past to create bigger declines in German market share; where political activism was high, the past mattered a great deal in amplifying changes in consumer behavior. These findings can be interpreted as highlighting the importance of social networks in overcoming collective action problems, such as in the case of boycotts.

\section{Discussion}

In this section, we discuss the implications of our findings. In particular, we examine for how long the effects of German-Greek conflict are visible in the data, and what the main results imply for the effects of memory on economic behavior.

\footnotetext{
${ }^{18}$ We cannot replicate our main analysis using Facebook membership as the dependent variable, since the time of joining a boycott group is not available.
} 


\subsection{Explaining the shift in market share}

One possibility is that consumers simply postpone purchases of German cars. In that case, a lost sale in one month will be made up by additional sales in later months. While the basic finding would still hold, the interpretation would be different - and the overall economic relevance would be less.

To deal with the possibility that purchases are postponed, we use a triple-difference specification, with log car sales as the dependent variable. Table 12 reports the results of this exercise, starting from a baseline specification of the form:

$$
\begin{aligned}
\log \left(y_{i j t}\right)= & \alpha+\lambda_{t}+\beta_{1} C_{t}+\beta_{2} D_{j}+\beta_{3} G_{i}+\gamma_{1} C_{t} * D_{j}+\gamma_{2} C_{t} * G_{i} \\
& +\gamma_{3} D_{j} * G_{i}+\delta\left(C_{t} * D_{j} * G_{i}\right)+\mathbf{X}_{j} \pi+\epsilon_{i j t}
\end{aligned}
$$

and successively adding a number of fixed effects and fixed effects interactions. Here, $G_{i}$ is a dummy that takes on the value 1 if brand $\mathrm{i}$ is German. The first thing that one can observe is that both German and other car brands experience a drop in their sales in conflict months. This is not surprising, given that our measure of conflict is bound to capture, apart from German-Greek political tension, part of the general effect of the crisis. This drop is larger for German cars in columns (5)-(7), when brand-year interactions are included. The triple-difference coefficient, which captures the effect of a conflict month on the gap between German and non-German cars in reprisal vs non-reprisal prefectures is always negative and highly significant.

If consumers in reprisal prefectures substituted German cars for non-German ones, we would expect non-German cars to rise in these prefectures in conflict months. Indeed, the interaction coefficient of a conflict month with the share of the population affected by reprisals captures just that. It is positive in all specifications and insignificant only in column (7), when all fixed effects and interactions are included together. Furthermore, its magnitude makes up for almost all of the extra drop that German car sales experience 
in reprisal prefectures. These results support the hypothesis that substitution is taking place. People are not simply waiting to buy their VW, they are buying a Peugeot instead.

\subsection{Duration of effects}

For how long does public conflict affect consumer behavior? It could well be that even in regions with a history of reprisal attacks, the effects of German-Greek conflict are short-term in nature, and disappear quickly. In that case, one interpretation of our results would be that even in places with a strong disposition towards animosity, not even severe public conflict can affect behavior for long - in line with the general conclusion in the boycott literature that effects are small at best.

In Figure 9, we plot the share of Kathimerini articles devoted to German-Greek conflict side-by-side with the difference in market share for German cars between reprisal and non-reprisal prefectures. Vertical lines indicate conflict months. Until the first event, the average difference in German market share between reprisal and non-reprisal towns fluctuates around zero; thereafter, the difference becomes large and negative, with particularly sharp declines during the months identified as periods of extreme negative sentiment between the two sides. This suggests that, while market share changes sharply from month to month in any one prefecture, the effect of conflict accumulates. By the end of our sample period, the difference in the market share of German cars between reprisal and non-reprisal prefectures has grown to more than 2 percentage points, approximately 2 standard deviations. There is certainly no evidence that the effect dissipates quickly after the three crisis months.

\subsection{Interpretation}

How do we make sense of our main finding - the fact that past conflict influences economic behavior to a different extent, depending on current conditions, and in a way that varies by location? Our results are compatible with a broader set of findings that 
emphasize cognitive limitations as a source of behavioral biases. Becker (1993) already highlighted the limitations of human memory as a key feature of economic behavior. Mullainathan (2002) provides a unified model in which imperfect recall can explain a range of experimental findings suggesting seemingly irrational behavior. Psychologists emphasize two aspects of memory - recall is associative, and it responds to rehearsal. Cues, such as the famous taste of a madeleine recalled by Proust's hero in A la recherche du temps perdu, can evoke memories. Remembering past incidents is systematically easier if they are similar to events in the present. Also, the more often a particular memory is evoked, the easier it will be to recall in the future (Schacter, 1996). This implies that, in the final analysis, even random events in the present may shape behavior, by recalling certain elements of the past and altering future memory recall (Mullainathan, 2002). Finally, memory seems to be reconstructive - people remember those aspects of the past that allow them to tell consistent stories. Parts that do not fit the explanatory model are much more likely to be left out (Bartlett, 1932).

The model that speaks most closely to our setting is Gennaioli and Shleifer (2010) on "what comes to mind". In their work, agents act as local thinkers. They possess only a limited capacity to process and store information. When evaluating a particular course of action, agents only consider a subset of all possible scenarios - the ones that are made salient by the context. In their model, agents have a preference for recalling representative scenarios. In their setting, acting on stereotypes will often be a useful strategy that imposes almost no costs on agents; in certain situations, however, these cognitive shortcuts will lead to major misapprehensions.

The behavior we document is compatible with the features of memory highlighted by psychologists and in earlier theoretical work in economics. The Euro crisis reduced the freedom of action of the Greek government, which had to rely on bailouts from its European partners. The German government in particular imposed harsh conditions, including severe expenditure cuts. As the placards carried by demonstrators show, the situation reminded many Greeks of the German occupation during World War II, which 
also left Greeks powerless to oppose any German diktat. As memories of World War II became more salient, seemingly consistent stories about the aberrant German national character gained traction. The surge in protest groups, calls for boycott, and the hatred expressed in demonstrations suggest that memories of war crimes were reactivated by the economic crisis. Such memories can become salient more readily in areas where people's families suffered at the hand of the occupying forces after 1941. Finally, as conflict erupted several times, its effects accumulated - repetition made it harder to forget the past, and the accumulated difference in market shares for German cars in reprisal prefectures kept increasing.

Our findings also highlight the role of emotions and fairness considerations in economicdecision making (Loewenstein, 2000). The heuristic of affect, or gut feeling, is commonly used by humans to guide behavior (Kahneman, 2011), and probably has evolutionary origins (Boyd and Richerson, 1985). When is its use more likely to be triggered? In an experimental study, Maheswaran and Chen (2006) show that, when primed with negative associations about a country, subjects are less likely to buy its products. Ethnocentrism and an emphasis on distinctions between in- and outgroups Kinder and Kam, 2009) only intensifies adverse reactions against the perceived mistreatment of one's own country. Studies in experimental psychology find that affect is more likely to inform a decision when experiences related to it have left a strong emotional impression in the past (Serman and Kim, 2002). The German occupation was a historical event that had such an emotional impact on many Greeks, and all the more so in areas that saw massacres and villages burned to the ground. Such events were likely to trigger an emotional response at the time of the Greek debt crisis, which underlined the Germans' position of power.

This also relates to the notion of fairness, which has been the subject of extensive research in game theory and experimental economics (Fehr and Gächter, 2000). Individuals are willing to deviate from individually optimal behavior when perceived fairness is violated, by, for example, losing money to punish those whose behavior was perceived 
as unfair. The notion of fairness is also known to be reference-dependent Kahneman et al. 1986). A perceived lack of fairness could have driven Greek consumer behavior during the crisis. The German side insisted on severe cutbacks in expenditures. Salary cuts combined with tax hikes strongly reduced disposable incomes compared to the recent past. Fairness considerations alone cannot explain the differential sales pattern we identify among Greek prefectures, but it is possible that they form part of the explanation for the general drop in German car sales during conflict months.

In the final analysis, our research cannot identify the precise channel responsible for the differential slump in car sales. The evidence is compatible with an interpretation emphasizing emotional responses, and in particular, anger at perceived unfair treatment at the hands of Germany. Where such anger combined with memories of earlier war crimes, consumer behavior suggests that the public-good logic - which in normal times stifles boycott participation - can be overcome, resulting in a powerful backlash.

\section{Conclusions}

Boycotts are among the most common means of collective political action today. Remarkably, few empirical studies have documented that consumers actually change their purchasing behavior in response. Free-riding on the moralizing behavior of others is a common temptation (Sen et al., 2001). At the same time, there is strong evidence that memories of past conflict linger, and continue to influence economic outcomes in the present. For example, countries that often went to war with each other in the past still trade less today (Guiso et al., 2009). This begs the question how armed conflict in the past can still influence consumer choice in the present, especially if boycotts in general "don't work".

We examine the case of Greece after the outbreak of the debt crisis in 2010. Forced to borrow from EU partners, the country had to implement severe austerity measures. Many of the policies implemented in exchange for the EU bailout packages were blamed on German policies. Public spats between German and Greek politicians deepened the 
impression of deeply-rooted antagonisms. The Greek public, when protesting, used Nazi-era symbols to express its outrage about German demands for more spending cuts and the perceived unfairness of conditions imposed on Greece. Press articles about German massacres during World War II increased in frequency.

These events affected consumer behavior in Greece. German car sales suffered in months of conflict, but not in a uniform way. In those areas where German occupying forces after 1941 had carried out reprisal measures - torching villages and killing the civilian population - saw the sharpest declines in German car sales. Prefectures where no major war crimes had been committed saw much smaller declines in car sales, or no significant change at all. This strongly suggests that public conflict matters for economic behavior when it revives latent animosity, reflecting an earlier history of conflict. In this way, past conflict begets more acrimony in the present. Cycles of conflict are driven by the way in which current events are interpreted through the lens of past experiences ${ }^{19}$

In normal times, boycotts are subject to severe collective action problems. Just as in the case of voting, the costs accrue at the individual level, while the benefits are generated in the aggregate. Our results suggest that this logic of individual choice can be overcome if public outrage is large enough. In particular, when contemporary events interact with memories of earlier outrages, consumer behavior can change in a major way - as was also the case with French automobile sales in China in the 2000s (reviving memories of the humiliation of China at the hands of Western powers) and with Sino-Japanese trade in 2005 (recalling the war crimes committed by Japan's armed forces during the invasion of China in the 1930s). 20 These findings are compatible with an interpretation emphasizing the importance of salience in economic decision-making Gennaioli and Shleifer (2010).

\footnotetext{
${ }^{19}$ Acemoglu and Wolitzky (2012) show that cycles of conflict can also contain the seeds of their own destruction - eventually, after repeated cycles of conflict, a Bayesian agent will conclude that bad actions are not necessarily a sign of bad intentions.

20 Hong et al. (2011); Fisman et al. (2012).
} 


\section{References}

Acemoglu, D. and Wolitzky, A. (2012). Cycles of Distrust: An Economic Model. Working Paper 18257, NBER.

Algan, Y. and Cahuc, P. (2010). Inherited Trust and Growth. American Economic Review, 100 (5), 2060-92.

Altonji, J. G., Elder, T. E. and Taber, C. R. (2005). Selection on Observed and Unobserved Variables: Assessing the Effectiveness of Catholic Schools. Journal of Political Economy, 113 (1), 151-184.

Ashenfelter, O., Ciccarella, S. and Shatz, H. J. (2007). French Wine and the U.S. Boycott of 2003: Does Politics Really Affect Commerce? Working Paper 13258, NBER.

Baker, S., Bloom, N. and Davis, S. J. (2013). Measuring Economic Policy Uncertainty. Working paper.

Bartlett, F. (1932). Remebering. Cambridge: Cambridge University Press.

Becker, G. S. (1993). Nobel Lecture: The Economic Way of Looking at Behavior. Journal of Political Economy, pp. 385-409.

Boyd, R. and Richerson, P. J. (1985). Culture and the Evolutionary Process. Chicago: University of Chicago Press.

Chaney, E. (2008). Tolerance, Religious Competition and the Rise and Fall of Muslim Science. mimeo, Harvard University.

Chavis, L. and Leslie, P. (2006). Consumer Boycotts: The Impact of the Iraq War on French Wine sales in the U.S. Working Paper 11981, NBER.

Chen, M. K. (2013). The Effect of Language on Economic Behavior: Evidence from Savings Rates, Health Behaviors, and Retirement Assets. American Economic Review, 103 (2), 690-731.

Danielson, J. and Gesch, D. (2010). Global Multi-Resolution Terrain Elevation Data 2010, (GMTED2010), Open File Report, U.S. Geological Survey.

Doxiadis, C. (1947). Thysies tis Ellados: Aitimata kai Epanorthoseis ston B' Pagosmio Polemo. Report 19, Hellenic Ministry of Reconstruction, Athens.

Fehr, E. and Gächter, S. (2000). Fairness and Retaliation: The Economics of Reciprocity. Journal of Economic Perspectives, 14 (3), 159-181.

Fernández, R. and Fogli, A. (2006). Fertility: The Role of Culture and Family Experience. Journal of the European Economic Association, 4 (2-3), 552-561.

Fernández-Villaverde, J., Greenwood, J. and Guner, N. (2011). From Shame to Game in One Hundred Years: The Rise in Premarital Sex and its Destigmitization. Discussion Paper 8667, CEPR. 
Fisman, R., Hamao, Y. and Yongxiang, W. (2012). The Impact of Cultural Aversion on Economic Exchange: Evidence from Shocks to Sino-Japanese Relations, working Paper.

Gennaioli, N. and Shleifer, A. (2010). What Comes to Mind. The Quarterly Journal of Economics, 125 (4), 1399-1433.

Guiso, L., Sapienza, P. and Zingales, L. (2007). Social Capital as Good Culture. Working Paper 13712, NBER.

- - — and - (2009). Cultural Biases in Economic Exchange? The Quarterly Journal of Economics, 124 (3), 1095-1131.

Hionidou, V. (2006). Famine and Death in Occupied Greece, 1941-1944. Cambridge: Cambridge University Press.

Hong, C., Hu, W.-M., Prieger, J. E. and Zhu, D. (2011). French Automobiles and the Chinese Boycotts of 2008: Politics Really Does Affect Commerce. The B.E. Journal of Economic Analysis \& Policy, 11 (1), 26.

John, A. and Klein, J. (2003). The Boycott Puzzle: Consumer Motivations for Purchase Sacrifice. Management Science, 49 (9), 1196-1209.

Kahneman, D. (2011). Thinking, Fast and Slow. New York: Farrar, Straus and Giroux.

-, Knetsch, J. L. and Thaler, R. (1986). Fairness as a Constraint on Profit Seeking: Entitlements in the Market. The American economic review, 76 (4), 728741.

- and Tversky, A. (1982). Judgment Under Uncertainty: Heuristics and Biases. New York: Cambridge University Press.

Kinder, D. R. and KAM, C. D. (2009). Us Against Them: Ethnocentric Foundations of American Opinion. Chicago: University of Chicago Press.

Koku, P. S., Aknigbe, A. and Springer, T. M. (1997). The Financial Impact of Boycotts and Threats of Boycott. Journal of Business Research, 40 (1), 15-20.

Loewenstein, G. (2000). Emotions in Economic Theory and Economic Behavior. American Economic Review, 90 (2), 426-432.

Maheswaran, D. and Chen, C. Y. (2006). Nation Equity: Incidental Emotions in Country-of-Origin Effect. Journal of Consumer Research, 33 (3), 370-376.

Mann, T. (1916). Friedrich und die Grosse Koalition. Berlin: S. Fischer.

Mazower, M. (1995). Inside Hitler's Greece: The Experience of Occupation, 19411944. New Haven and London: Yale University Press.

Meyer, H. F. (2002). Von Wien nach Kalavryta. Die blutige Spur der 11\%. JägerDivision durch Serbien und Griechenland. Mannheim: Peleus. 
Michaels, G. and Zhi, X. (2010). Freedom Fries. American Economic Journal: Applied Economics, 2 (3), 256-81.

Mullainathan, S. (2002). A Memory-Based Model Of Bounded Rationality. The Quarterly Journal of Economics, 117 (3), 735-774.

Nessou, A. (2009). Deutsche Besatzungspolitik und Verbrechen gegen die Zivilbevölkerung - eine Beurteilung nach dem Volkerrecht. Göttingen: Vandenhoeck \& Ruprecht.

Nunn, N. and Wantchekon, L. (2011). The Slave Trade and the Origins of Mistrust in Africa. American Economic Review, 101 (7), 3221-52.

Pandya, S. and Venkatesan, R. (2012). French Roast: International Conflict and Consumer Boycotts - Evidence from Supermarket Scanner Data.

Riley, S. J., DeGloria, S. D. and Elliot, R. (1999). A Terrain Ruggedness Index That Quanties Topographic Heterogeneity. International Journal of Sciences, 5 (1).

Schacter, D. (1996). Searching for Memory: The Brain, the Mind and the Past. New York: Basic Books.

Sen, S., Gurhan-Canli, Z. and Morwitz, V. (2001). Withholding Consumption: A Social Dilemma Perspective on Consumer Boycotts. Journal of Consumer Research, 28 (3), 399-417.

Serman, D. and Kim, H. (2002). Affective Perseverance: The Resistance of Affect to Cognitive Invalidation. Personality and Social Psychology Bulletin, 28 (2), 224237.

Subministry of Reconstruction (1946). Pinakes Katastrofwn Oikodomwn ths Ellados. Edition series no. 104 2, Hellenic Subministry of Reconstruction, Athens.

TeOh, S. H., Welch, I. and Wazzan, C. P. (1999). The Effect of Socially Activist Investment Policies on the Financial Markets: Evidence from the South African Boycott. The Journal of Business, 72 (1), 35-89.

Voigtränder, N. and Voth, H.-J. (2012). Persecution Perpetuated: The Medieval Origins of Anti-Semitic Violence in Nazi Germany. The Quarterly Journal of Economics, 127 (3), 1339-1392. 


\section{A Tables and Figures}

Figure 1: Changes in the Market Share of German Cars
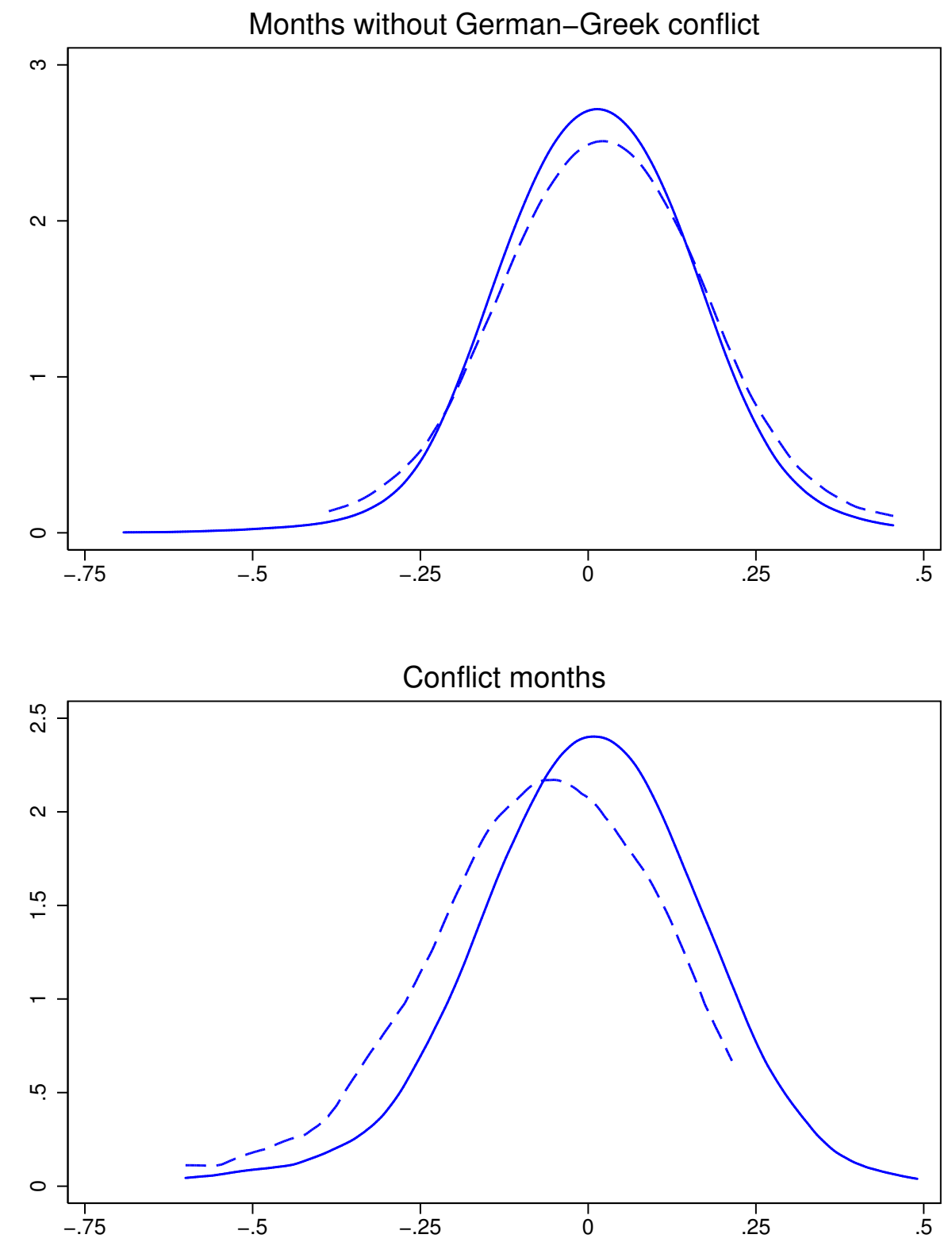

Reprisal, lower quartiles $\quad----$ Reprisal, highest quartile

Notes: The graph shows changes in the market share of German cars, comparing to the same month a year earlier. The upper panel shows changes during periods without German-Greek conflict; the lower panel, during months of public conflict (for definition of conflict, cf the data section). In each panel, we plot the distribution of market share changes separately for prefectures in the lower three and in the upper quartile of population affected by German massacres during World War II, relative to the size of the pre-1940 population. 
Figure 2: Map of Towns Affected by German Reprisals, 1941-1944

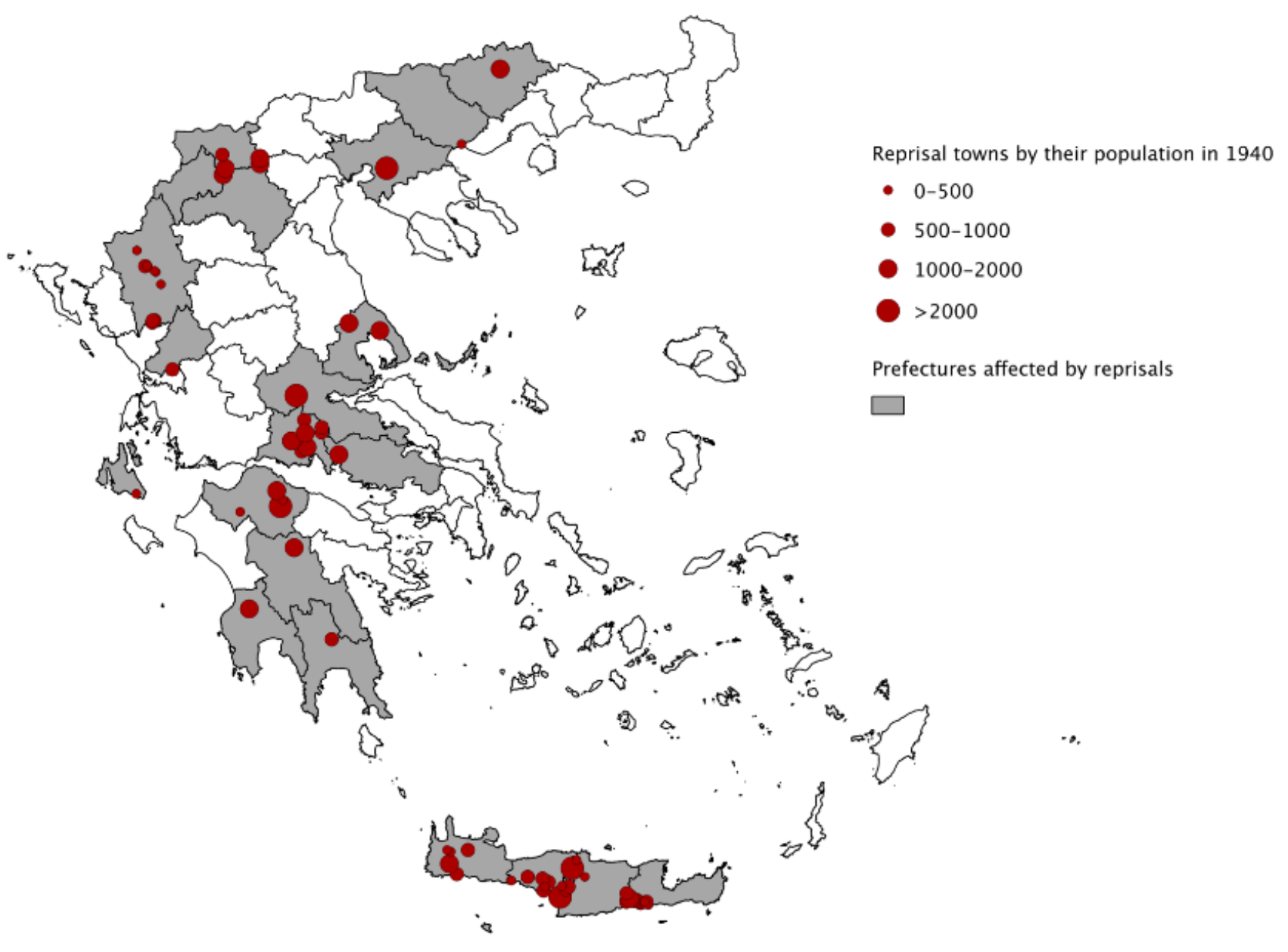

Notes: "Martyred towns", as characterized by presidential decrees no. 399 (1998), 99 (2000), 40 (2004) and 140 (2005). Population data from the 1940 Greek Census. 
Figure 3: Number of International News Articles Referring to German-Greek Conflict

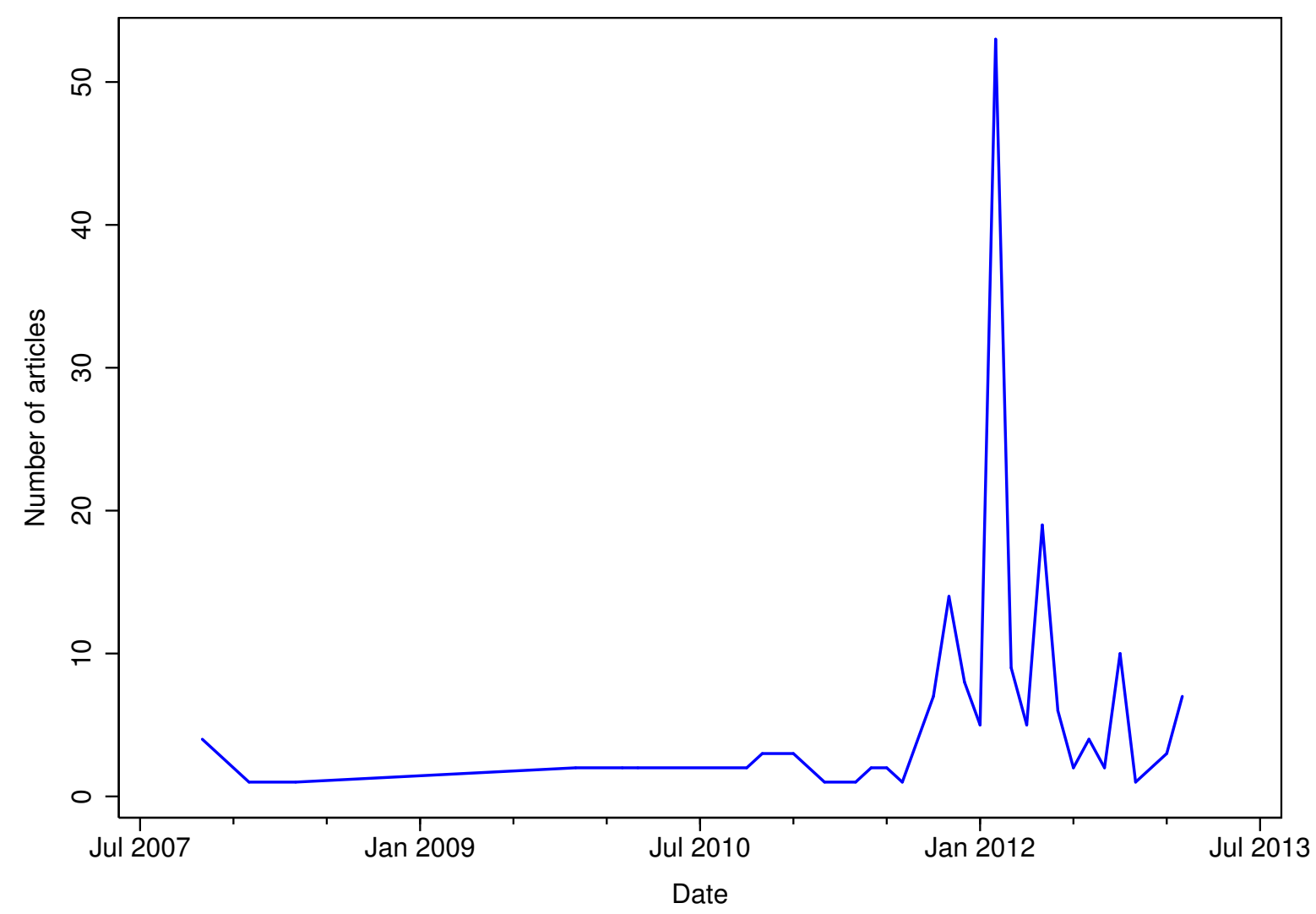

Notes: Number of international newspaper articles in English that mention the words "anti-German" and "Greece".

Source: LexisNexis. 
Figure 4: News-based Index of German-Greek Conflict

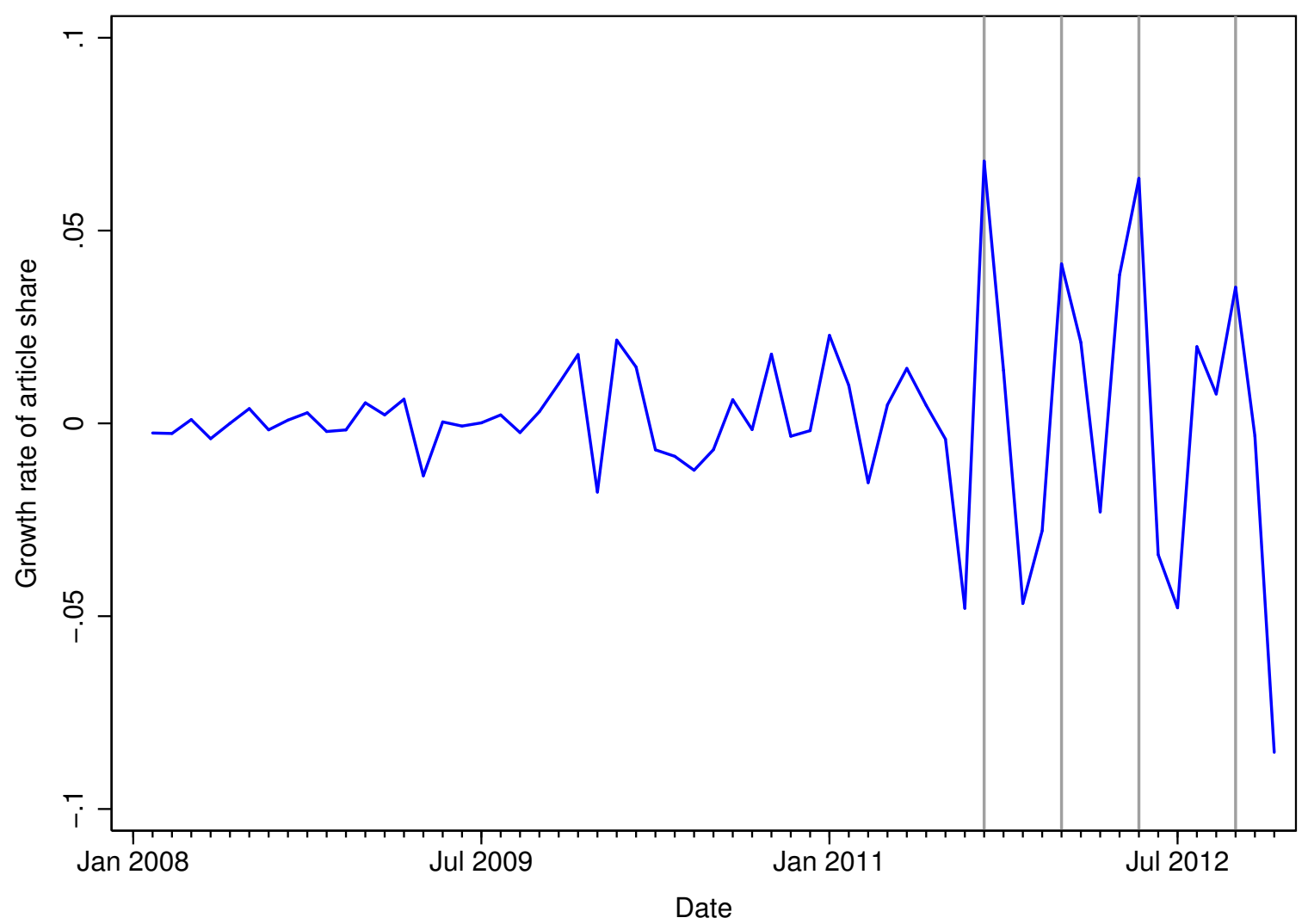

Notes: The figure depicts the growth rate in the monthly share of Kathimerini articles relating to German-Greek conflict (for details, cf. the data section and data appendix). The vertical reference lines indicate a local peak in the series that is larger than one standard deviation. 
Figure 5: Share of German Cars, Greece vs Western Europe

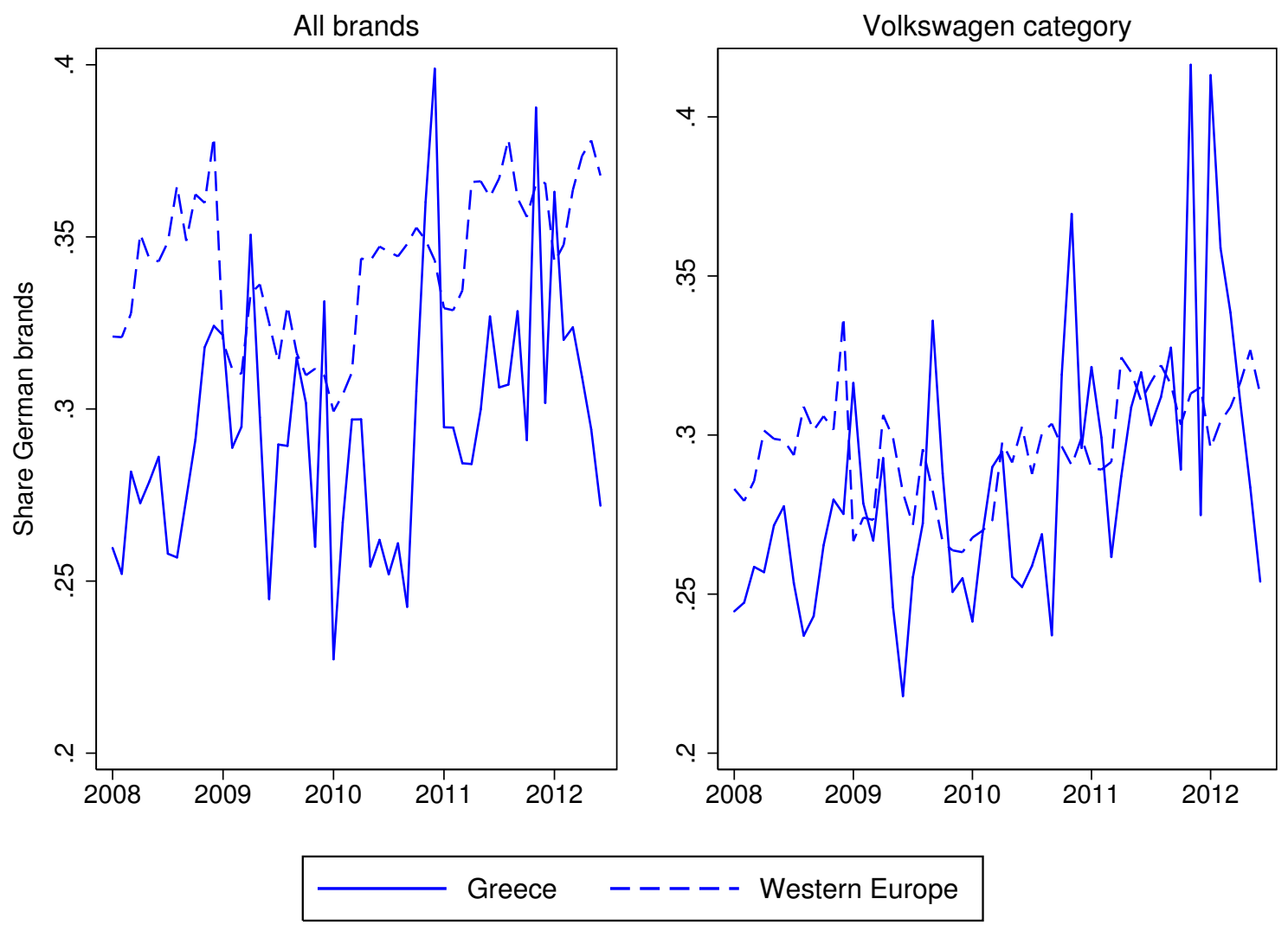

Notes: Monthly share of German cars in the total number of new cars registered. Western Europe includes Austria, Belgium, Denmark, Finland, France, Greece, Germany, Ireland, Italy, Luxembourg, the Netherlands, Portugal, Spain, Sweden, the UK, Iceland, Norway and Switzerland. The Volkswagen category includes Volkswagen, Opel, Citroen, Ford, Honda, Hyundai, Nissan, Peugeot, Renault, Seat, Skoda and Toyota. Data from Hel.Stat. and Association Auxiliaire de l'Automobile (AAA). 
Figure 6: Effect of a Conflict Month on the Market Share of German Cars

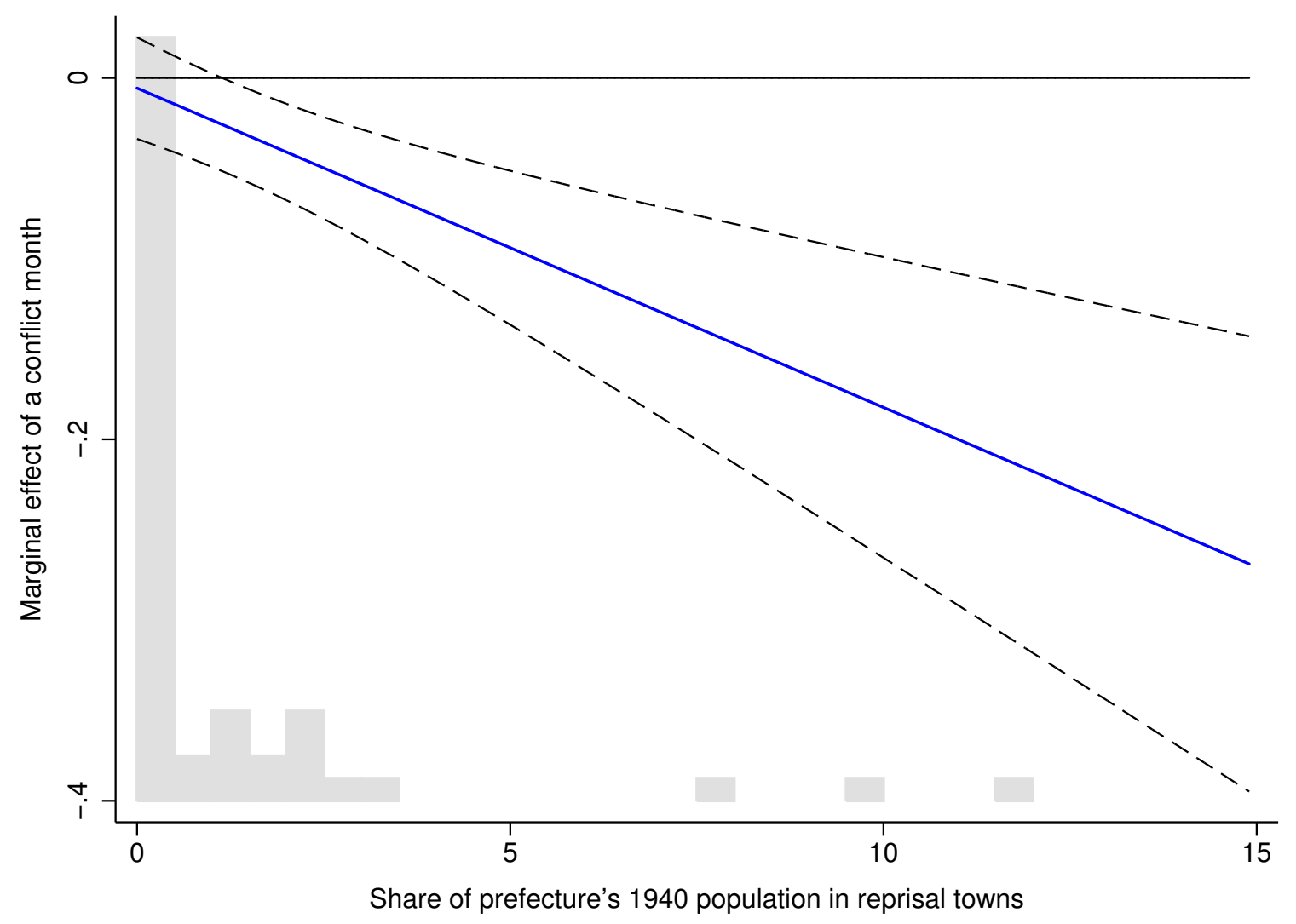

Notes: Estimated marginal effect and 95\% confidence interval from regression reported in column (3) of Table 6. Panel B. The histogram plots the distribution of prefectures by share of their 1940 population affected by reprisals. 
Figure 7: Comparison of News and Search-Based Conflict Index

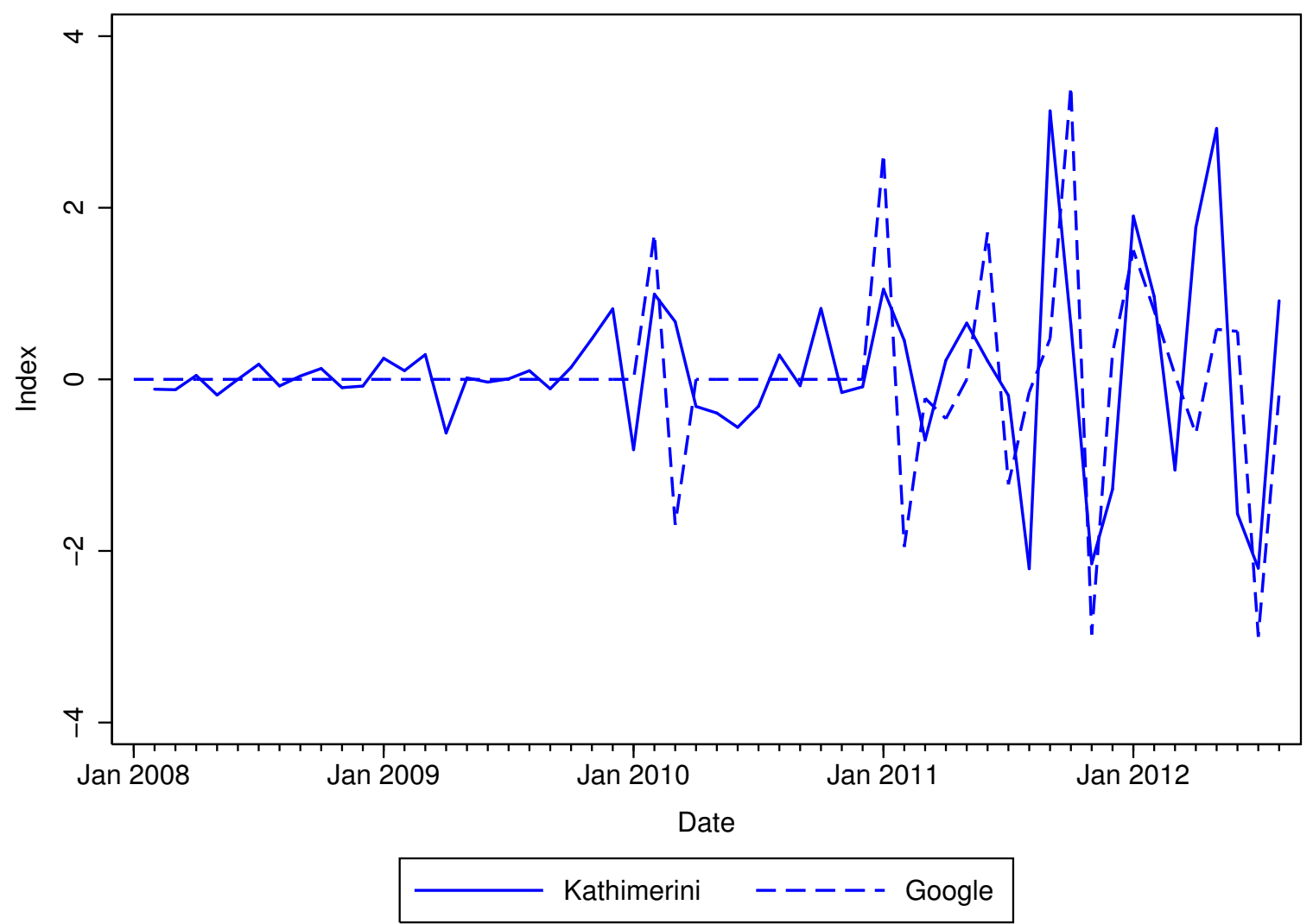

Notes: The solid line is the growth rate in the monthly share of Kathimerini articles related to German-Greek conflict. The dashed line is the average growth rate in the Google Trends search index for the terms "Germans", "German reparations" and "Distomo". Both series are normalized by their standard deviation. 


\section{Figure 8: Facebook Membership in Boycott Groups}

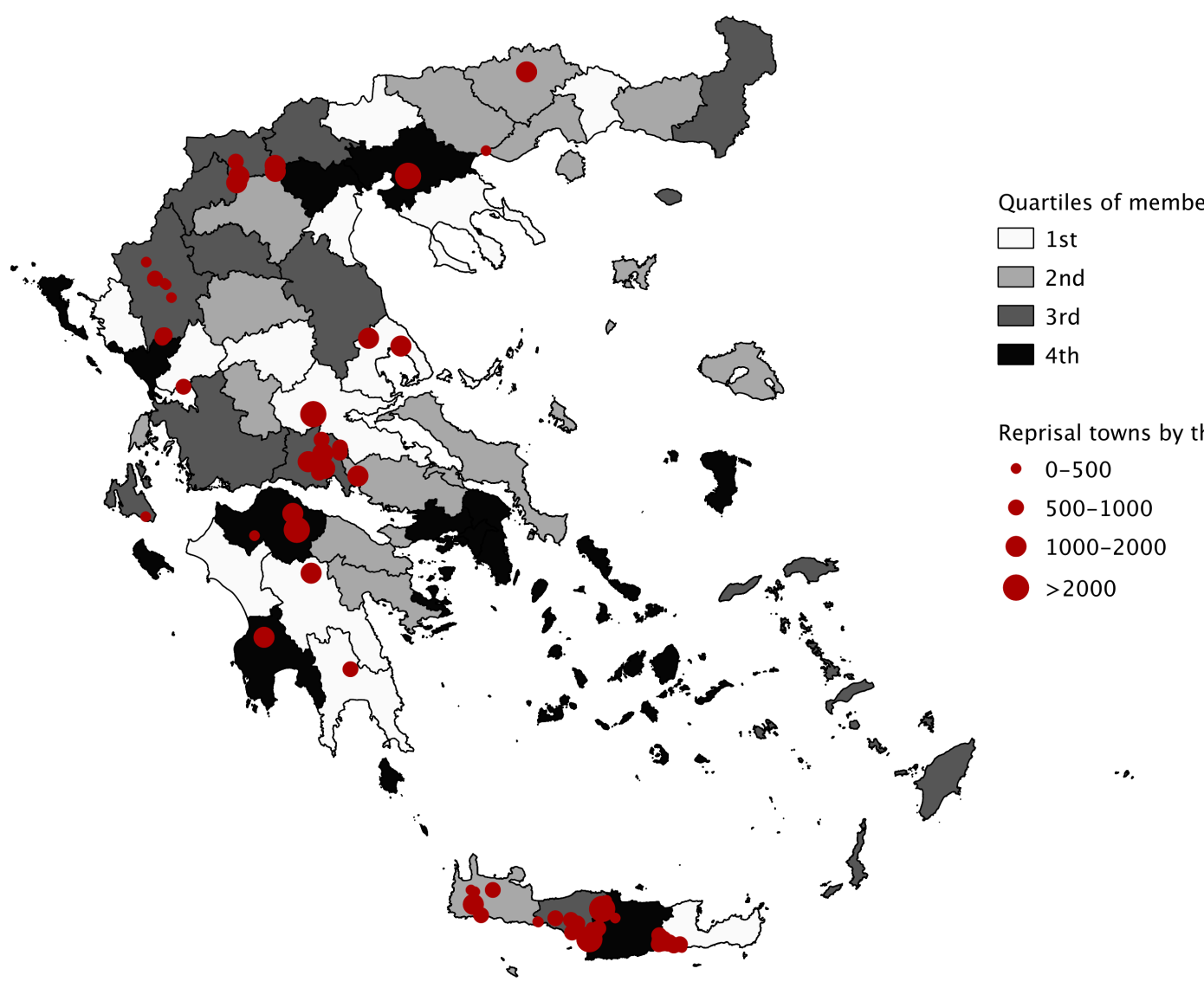

Notes: The map depicts by prefecture the number of members of Facebook groups calling for the boycott of German products, normalized by prefecture population. Member locations come from publicly viewable entries in the field "Current City". Data on reprisal towns are from presidential decrees no. 399 (1998), 99 (2000), 40 (2004) and 140 (2005). Population data are from the 1940 and 2001 Greek Census. 
Figure 9: German-Greek Conflict and Evolution of German Market Share in Prefectures With and Without Reprisals

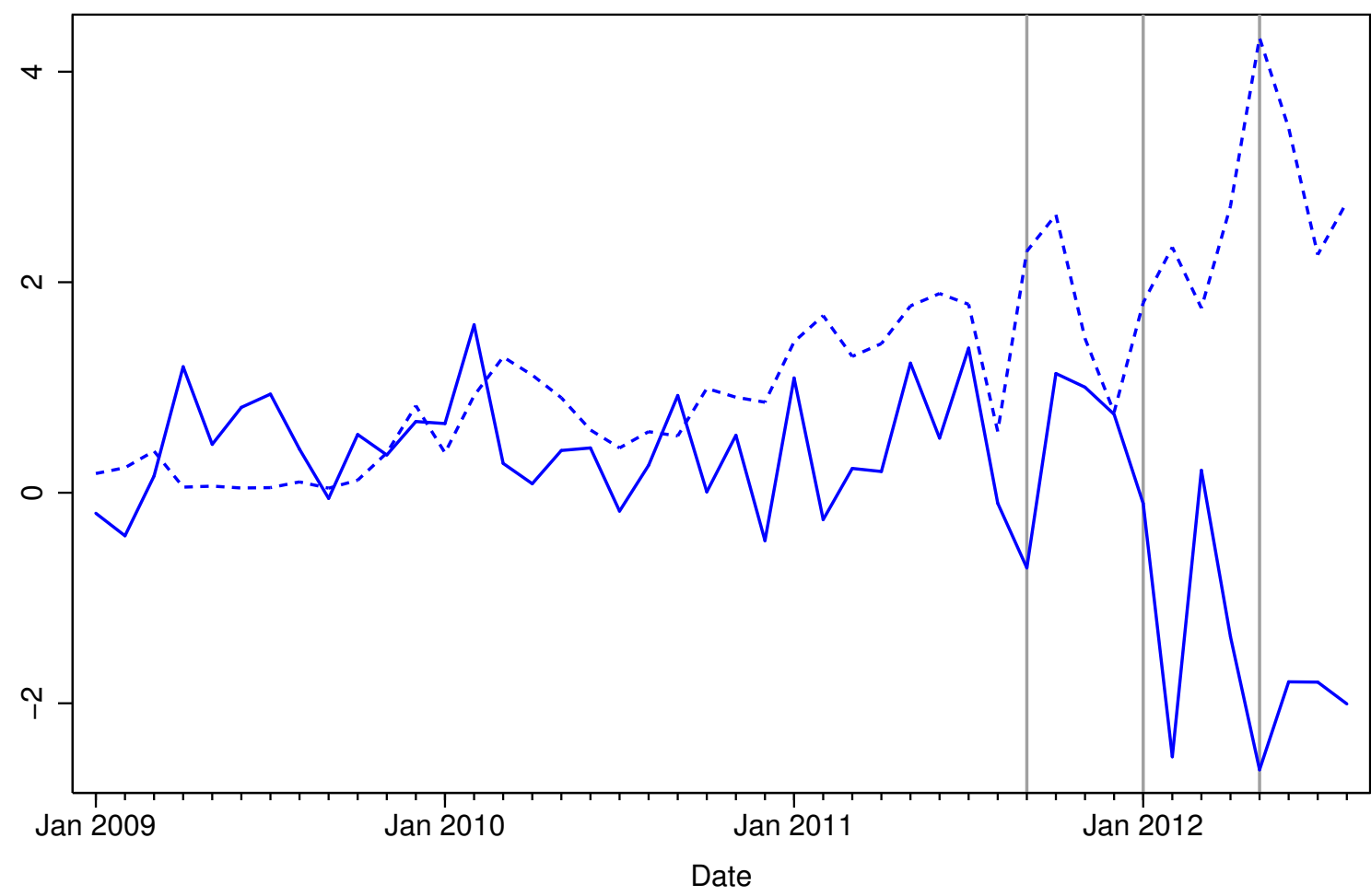

German share, reprisal-non reprisal

Article share

Notes: The solid line is the difference in the seasonally adjusted (expressed as difference of month $\mathrm{t}$ from month t-12) share of German car registrations in the Volkswagen category in reprisal vs non-reprisal prefectures. The dotted line is the monthly share of Kathimerini articles related to German-Greek conflict. Both series are normalized by their standard deviation. 
Table 1: Chronology of Greek Crisis and German-Greek Conflict Month Identification

\begin{tabular}{|c|c|}
\hline Date & Event Description \\
\hline \multirow[t]{3}{*}{ February 2010} & Deal with EU/ECB/IMF on bailout and first austerity package \\
\hline & $\begin{array}{l}\text { Cover of Focus magazine with title "Cheaters in the Euro-family" dis- } \\
\text { plays Aphrodite of Milos making rude gesture }\end{array}$ \\
\hline & $\begin{array}{l}\text { Greek Consumer Association calls consumers to boycott German prod- } \\
\text { ucts }\end{array}$ \\
\hline \multirow[t]{3}{*}{ October 2010} & Germany refuses time extension for repayment of Greek loans \\
\hline & $\begin{array}{l}\text { Brussels EU summit sees acceptance of German-engineered new bailout } \\
\text { mechanism }\end{array}$ \\
\hline & $\begin{array}{l}\text { Merkel-Sarkozy suggestion that indebted countries are stripped of voting } \\
\text { rights causes angry responses from Greek politicians }\end{array}$ \\
\hline January 2011 & Case of German reparations for WWII crimes on trial in den Haag \\
\hline \multirow[t]{2}{*}{ May 2011} & Discussions for new round of austerity measures (Midterm plan) \\
\hline & $\begin{array}{l}\text { Merkel comment on "lazy Southerners" at political rally attracts large } \\
\text { attention in Greek press }\end{array}$ \\
\hline \multirow[t]{3}{*}{ September 2011} & $\begin{array}{l}\text { Eurogroup meeting in Brussels pressures Greece to go through with re- } \\
\text { forms }\end{array}$ \\
\hline & $\begin{array}{l}\text { Greek government implements new measures including firings and pen- } \\
\text { sion cuts }\end{array}$ \\
\hline & $\begin{array}{l}\text { German Finance minister says it is the Greeks' decision whether they } \\
\text { want to leave the euro, while FDP members suggest a Greek orderly } \\
\text { default }\end{array}$ \\
\hline \multirow[t]{2}{*}{ October 2011} & New austerity package is voted amidst severe rioting \\
\hline & $50 \%$ "haircut" of Greek debt takes place \\
\hline January 2012 & $\begin{array}{l}\text { EU commission rejects "German plan" for Greece to relinquish budget } \\
\text { control }\end{array}$ \\
\hline \multirow[t]{3}{*}{ February 2012} & Parliament approves new austerity plan \\
\hline & $\begin{array}{l}\text { International court rules in favor of Germany in trial regarding WWII } \\
\text { reparations }\end{array}$ \\
\hline & $\begin{array}{l}\text { Greek President Carolos Papoulias declares "I cannot accept Mr Schaeu- } \\
\text { ble insulting my country" }\end{array}$ \\
\hline \multirow[t]{2}{*}{ May 2012} & Month of Greek national elections \\
\hline & $\begin{array}{l}\text { German ministers remind Greece that measures have to be carried } \\
\text { through irrespective of government outcome, if the country wants to re- } \\
\text { main in the Eurozone }\end{array}$ \\
\hline
\end{tabular}

Dates in bold are turning points in the growth series of the conflict-related article share of Kathimerini. 
Table 2: Monthly Car Registrations in Greece

\begin{tabular}{|c|c|c|c|c|}
\hline Manufacturer & Mean & S.D. & Min & Max \\
\hline AUDI & 389 & 277 & 99 & 1543 \\
\hline BMW & 455 & 318 & 90 & 1334 \\
\hline BENTLEY & 1 & 1 & 0 & 5 \\
\hline CHANG'AN & 3 & 3 & 0 & 15 \\
\hline CHEVROLET & 230 & 188 & 5 & 698 \\
\hline CHRYSLER & 91 & 94 & 0 & 361 \\
\hline CITROEN & 493 & 296 & 87 & 1358 \\
\hline DACIA & 41 & 30 & 0 & 99 \\
\hline DAIHATSU & 243 & 232 & 4 & 783 \\
\hline DAIMLER & 645 & 472 & 51 & 1785 \\
\hline FERRARI & 1 & 2 & 0 & 7 \\
\hline FIAT $^{\mathrm{a}}$ & 953 & 488 & 269 & 2513 \\
\hline FORD & 897 & 506 & 216 & 2087 \\
\hline GENERAL MOTORS & 25 & 32 & 0 & 129 \\
\hline HONDA & 281 & 232 & 36 & 1025 \\
\hline HYUNDAI & 841 & 625 & 133 & 2524 \\
\hline JAGUAR & 7 & 11 & 0 & 48 \\
\hline JIANGLING & 0 & 0 & 0 & 2 \\
\hline KIA & 332 & 285 & 33 & 1636 \\
\hline LADA & 10 & 13 & 0 & 52 \\
\hline LAMBORGHINI & 0 & 1 & 0 & 3 \\
\hline LAND ROVER & 15 & 20 & 0 & 79 \\
\hline LOTUS & 0 & 1 & 0 & 2 \\
\hline MASERATI & 1 & 1 & 0 & 4 \\
\hline MAZDA & 285 & 311 & 2 & 1081 \\
\hline MITSUBISHI & 221 & 169 & 25 & 675 \\
\hline NISSAN & 685 & 444 & 86 & 1998 \\
\hline OPEL & 1202 & 613 & 384 & 2806 \\
\hline PEUGEOT & 504 & 335 & 97 & 1319 \\
\hline PORSCHE & 19 & 19 & 0 & 67 \\
\hline RENAULT & 215 & 136 & 65 & 723 \\
\hline SAAB & 36 & 40 & 0 & 194 \\
\hline SEAT & 423 & 308 & 45 & 1227 \\
\hline SHUANGHUAN AUTO & 4 & 5 & 0 & 18 \\
\hline SKODA & 511 & 294 & 138 & 1439 \\
\hline SSANGYONG & 10 & 13 & 0 & 57 \\
\hline SUBARU & 71 & 66 & 0 & 251 \\
\hline SUZUKI & 695 & 532 & 91 & 1896 \\
\hline TOYOTA & 1452 & 888 & 284 & 3909 \\
\hline VOLKSWAGEN & 1182 & 622 & 220 & 2436 \\
\hline VOLVO & 136 & 73 & 30 & 319 \\
\hline
\end{tabular}

${ }^{a}$ Includes Alfa Romeo and Lancia.

Source: Hel.Stat. Data for the period January 2008 to August 2012. 
Table 3: Summary Statistics of Main Variables

\begin{tabular}{|c|c|c|c|c|c|}
\hline Variable & Mean & S.D. & Min & $\operatorname{Max}$ & $\mathrm{N}$ \\
\hline \multicolumn{6}{|l|}{ Cross-section } \\
\hline Massacre in prefecture $(0 / 1)$ & 0.412 & 0.497 & 0 & 1 & 51 \\
\hline Share population in reprisal towns & 1.082 & 2.415 & 0 & 11.99 & 51 \\
\hline \multicolumn{6}{|l|}{ Panel } \\
\hline Total car sales & 266.8 & 1,138 & 0 & 16,361 & 2,856 \\
\hline Share german cars (all brands) & 0.251 & 0.117 & 0 & 1 & 2847 \\
\hline Share german cars (VW category) & 0.278 & 0.138 & 0 & 1 & 2,837 \\
\hline Conflict month $(0 / 1)$ & 0.107 & 0.309 & 0 & 1 & 2,856 \\
\hline
\end{tabular}


Table 4: Balancedness

\begin{tabular}{|c|c|c|c|c|}
\hline Variable & All & $\begin{array}{l}\text { Non- } \\
\text { reprisal }\end{array}$ & Reprisal & Difference \\
\hline Population & $\begin{array}{c}428,711 \\
(1,093,791)\end{array}$ & $\begin{array}{c}481,133 \\
(1,385,816)\end{array}$ & $\begin{array}{c}353,823 \\
(442,978)\end{array}$ & $\begin{array}{c}127,309 \\
(270,851)\end{array}$ \\
\hline Share employed in agriculture & $\begin{array}{c}0.264 \\
(0.107)\end{array}$ & $\begin{array}{c}0.277 \\
(0.110)\end{array}$ & $\begin{array}{c}0.245 \\
(0.102)\end{array}$ & $\begin{array}{c}0.0326 \\
(0.0300)\end{array}$ \\
\hline Share employed in industry & $\begin{array}{c}0.219 \\
(0.058)\end{array}$ & $\begin{array}{c}0.211 \\
(0.045)\end{array}$ & $\begin{array}{c}0.230 \\
(0.073)\end{array}$ & $\begin{array}{l}-0.0189 \\
(0.0179)\end{array}$ \\
\hline Share civil servants & $\begin{array}{c}0.014 \\
(0.004)\end{array}$ & $\begin{array}{c}0.014 \\
(0.004)\end{array}$ & $\begin{array}{c}0.013 \\
(0.003)\end{array}$ & $\begin{array}{c}0.001 \\
(0.001)\end{array}$ \\
\hline Share secondary education & $\begin{array}{c}0.179 \\
(0.031)\end{array}$ & $\begin{array}{c}0.170 \\
(0.030)\end{array}$ & $\begin{array}{c}0.192 \\
(0.030)\end{array}$ & $\begin{array}{c}-0.0212^{* *} \\
(0.009)\end{array}$ \\
\hline Share higher education & $\begin{array}{c}0.110 \\
(0.024)\end{array}$ & $\begin{array}{c}0.107 \\
(0.024)\end{array}$ & $\begin{array}{c}0.114 \\
(0.023)\end{array}$ & $\begin{array}{r}-0.0075 \\
(0.007)\end{array}$ \\
\hline Unemployment rate & $\begin{array}{c}0.122 \\
(0.029)\end{array}$ & $\begin{array}{c}0.119 \\
(0.025)\end{array}$ & $\begin{array}{c}0.126 \\
(0.035)\end{array}$ & $\begin{array}{l}-0.007 \\
(0.009)\end{array}$ \\
\hline Population in 1940 & $\begin{array}{c}146,868 \\
(177,369)\end{array}$ & $\begin{array}{c}147,034 \\
(223,671)\end{array}$ & $\begin{array}{l}146,637 \\
(83,881)\end{array}$ & $\begin{array}{c}397 \\
(45,389)\end{array}$ \\
\hline $\begin{array}{l}\text { Share of } 1940 \text { population } \\
\text { in reprisal towns }\end{array}$ & $\begin{array}{c}1.082 \\
(2.415)\end{array}$ & - & $\begin{array}{c}2.627 \\
(3.213)\end{array}$ & - \\
\hline Share destroyed housing & $\begin{array}{c}0.137 \\
(0.122)\end{array}$ & $\begin{array}{c}0.134 \\
(0.143)\end{array}$ & $\begin{array}{c}0.142 \\
(0.087)\end{array}$ & $\begin{array}{l}-0.008 \\
(0.033)\end{array}$ \\
\hline $\begin{array}{l}\text { Share seats to communists } \\
\text { in } 1936\end{array}$ & $\begin{array}{c}0.028 \\
(0.057)\end{array}$ & $\begin{array}{c}0.026 \\
(0.056)\end{array}$ & $\begin{array}{c}0.031 \\
(0.060)\end{array}$ & $\begin{array}{l}-.0047 \\
(0.0167)\end{array}$ \\
\hline Ruggedness & $\begin{array}{l}248.92 \\
(77.25)\end{array}$ & $\begin{array}{l}232.01 \\
(79.66)\end{array}$ & $\begin{array}{l}273.08 \\
(68.40)\end{array}$ & $\begin{array}{l}-41.07^{*} \\
(20.84)\end{array}$ \\
\hline Average distance from 1940 road & $\begin{array}{c}15.31 \\
(35.42)\end{array}$ & $\begin{array}{c}22.37 \\
(45.09)\end{array}$ & $\begin{array}{l}5.23 \\
(2.52)\end{array}$ & $\begin{array}{c}17.13^{* *} \\
(8.25)\end{array}$ \\
\hline Average distance from 1940 railway line & $\begin{array}{c}78.17 \\
(92.13)\end{array}$ & $\begin{array}{c}73.54 \\
(83.06)\end{array}$ & $\begin{array}{c}84.77 \\
(105.53)\end{array}$ & $\begin{array}{l}-11.23 \\
(27.57)\end{array}$ \\
\hline $\mathrm{N}$ & 51 & 30 & 21 & \\
\hline
\end{tabular}

Reprisal prefectures have at least one "martyred" town. Source: 2001 and 1940 Greek Census, Hellenic Subministry of Reconstruction and Hellenic Parliament, Registry of Parliament Members. 
Table 5: Change in the Average Share of German Cars

\begin{tabular}{lccc}
\hline & \multicolumn{3}{c}{ Panel A: All brands } \\
\cline { 2 - 4 } & Conflict months & Other months & Difference \\
\cline { 2 - 4 } & $(1)$ & $(2)$ & $(3)$ \\
\hline Reprisal prefectures & -0.0192 & 0.0193 & $-0.0384^{* * *}$ \\
Non-reprisal prefectures & $(0.0124)$ & $(0.0049)$ & $(0.0133)$ \\
& 0.0155 & 0.0189 & -0.0035 \\
Difference & $(0.0104)$ & $(0.0041)$ & $(0.0112)$ \\
& $-0.0346^{* *}$ & 0.0035 & $-0.0350^{* *}$ \\
& $(0.0162)$ & $(0.0112)$ & $(0.0174)$ \\
\hline \multirow{2}{*}{ Panel B: VW category } \\
\cline { 2 - 4 } Reprisal prefectures & Conflict months & Other months & Difference \\
\cline { 2 - 4 } & $(1)$ & $(2)$ & $(3)$ \\
\hline Non-reprisal prefectures & -0.0338 & 0.0341 & $-0.0679^{* * *}$ \\
& $(0.0145)$ & $(0.0057)$ & $(0.0155)$ \\
& 0.0220 & 0.0291 & -0.0070 \\
& $(0.0122)$ & $(0.0048)$ & $(0.0131)$ \\
& $-0.0559^{* * *}$ & 0.0050 & $-0.0608^{* * *}$ \\
& $(0.0189)$ & $(0.0075)$ & $(0.0204)$ \\
\hline
\end{tabular}

The share of German cars is seasonally adjusted and expressed as the difference between month $\mathrm{t}$ and $\mathrm{t}-12$. Reprisal prefectures have at least one "martyred" town. The Volkswagen category includes the following brands: Volkswagen, Opel, Citroen, Ford, Honda, Hyundai, Nissan, Peugeot, Renault, Seat, Skoda, Toyota. Significance levels: ${ }^{* * *} \mathrm{p}<0.01,{ }^{*} \mathrm{p}<0.05,{ }^{*} \mathrm{p}<0.1$. Standard errors in parentheses. 
Table 6: Share of German Cars, Baseline

\begin{tabular}{|c|c|c|c|c|c|c|}
\hline & (1) & $(2)$ & (3) & (4) & $(5)$ & $(6)$ \\
\hline \multicolumn{7}{|l|}{ Panel A: All brands } \\
\hline Conflict month & $\begin{array}{c}-0.0405^{* *} \\
(0.0189)\end{array}$ & $\begin{array}{r}-0.00508 \\
(0.0183)\end{array}$ & $\begin{array}{r}-0.00554 \\
(0.0112)\end{array}$ & $\begin{array}{r}-0.00552 \\
(0.0113)\end{array}$ & $\begin{array}{c}0.152 \\
(0.290)\end{array}$ & $\begin{array}{c}0.203 \\
(0.229)\end{array}$ \\
\hline Share pop. affected & & & $\begin{array}{c}0.00105 \\
(0.00131)\end{array}$ & $\begin{array}{c}0.000573 \\
(0.000969)\end{array}$ & $\begin{array}{c}0.000691 \\
(0.000961)\end{array}$ & \\
\hline $\begin{array}{l}\text { Conflict month* } \\
\text { Share pop. affected }\end{array}$ & & & $\begin{array}{c}-0.0132^{* * *} \\
(0.00279)\end{array}$ & $\begin{array}{r}-0.0132^{* * *} \\
(0.00280)\end{array}$ & $\begin{array}{c}-0.0141^{* * *} \\
(0.00397)\end{array}$ & $\begin{array}{l}-0.0157^{* *} \\
(0.00606)\end{array}$ \\
\hline Observations & 924 & 1309 & 2233 & 2233 & 2233 & 2233 \\
\hline R-squared & 0.0697 & 0.0362 & 0.0431 & 0.0487 & 0.0508 & 0.159 \\
\hline \multicolumn{7}{|c|}{ Panel B: Volkswagen category } \\
\hline Conflict month & $\begin{array}{c}-0.0555^{* *} \\
(0.0253)\end{array}$ & $\begin{array}{l}-0.00819 \\
(0.0213)\end{array}$ & $\begin{array}{l}-0.00567 \\
(0.0143)\end{array}$ & $\begin{array}{r}-0.00571 \\
(0.0143)\end{array}$ & $\begin{array}{c}0.171 \\
(0.412)\end{array}$ & $\begin{array}{c}0.282 \\
(0.396)\end{array}$ \\
\hline Share pop. affected & & & $\begin{array}{c}0.00261 \\
(0.00168)\end{array}$ & $\begin{array}{c}0.00196 \\
(0.00157)\end{array}$ & $\begin{array}{c}0.00225 \\
(0.00148)\end{array}$ & \\
\hline $\begin{array}{l}\text { Conflict month* } \\
\text { Share pop. affected }\end{array}$ & & & $\begin{array}{c}-0.0177^{* * *} \\
(0.00460)\end{array}$ & $\begin{array}{r}-0.0177^{* * *} \\
(0.00461)\end{array}$ & $\begin{array}{c}-0.0199^{* * *} \\
(0.00573)\end{array}$ & $\begin{array}{r}-0.0181^{* * *} \\
(0.00643)\end{array}$ \\
\hline Observations & 923 & 1298 & 2221 & 2221 & 2221 & 2221 \\
\hline R-squared & 0.0611 & 0.0373 & 0.0372 & 0.0429 & 0.0475 & 0.149 \\
\hline Controls & No & No & No & Yes & Yes & No \\
\hline Prefecture $\times$ Year & No & No & No & No & No & Yes \\
\hline $\begin{array}{l}\text { Controls } \times \\
\text { Conflict month }\end{array}$ & No & No & No & No & Yes & Yes \\
\hline
\end{tabular}

Significance levels: ${ }^{* * *} \mathrm{p}<0.01,{ }^{* *} \mathrm{p}<0.05,{ }^{*} \mathrm{p}<0.1$. Years 2008-2012. The dependent variable is the 12-month difference in the monthly German share of new cars registered in a prefecture. The Volkswagen category includes the following brands: Volkswagen, Opel, Citroen, Ford, Honda, Hyundai, Nissan, Peugeot, Renault, Seat, Skoda, Toyota. Column (1) is restricted to prefectures with at least one reprisal town. Column (2) is restricted to prefectures wthout reprisals. Columns (3)-(6) use the entire sample. All regressions include year fixed effects. Prefecture controls include $\log$ (population) in 2001, share employed in agriculture in 2001, share employed in industry in 2001, share with higher education in 2001 , share with secondary education in 2001, unemployment rate in 2001, ruggedness, average distance from the nearest road in 1940 and average distance from the nearest railway line in 1940. Standard errors are clustered at the prefecture level. 


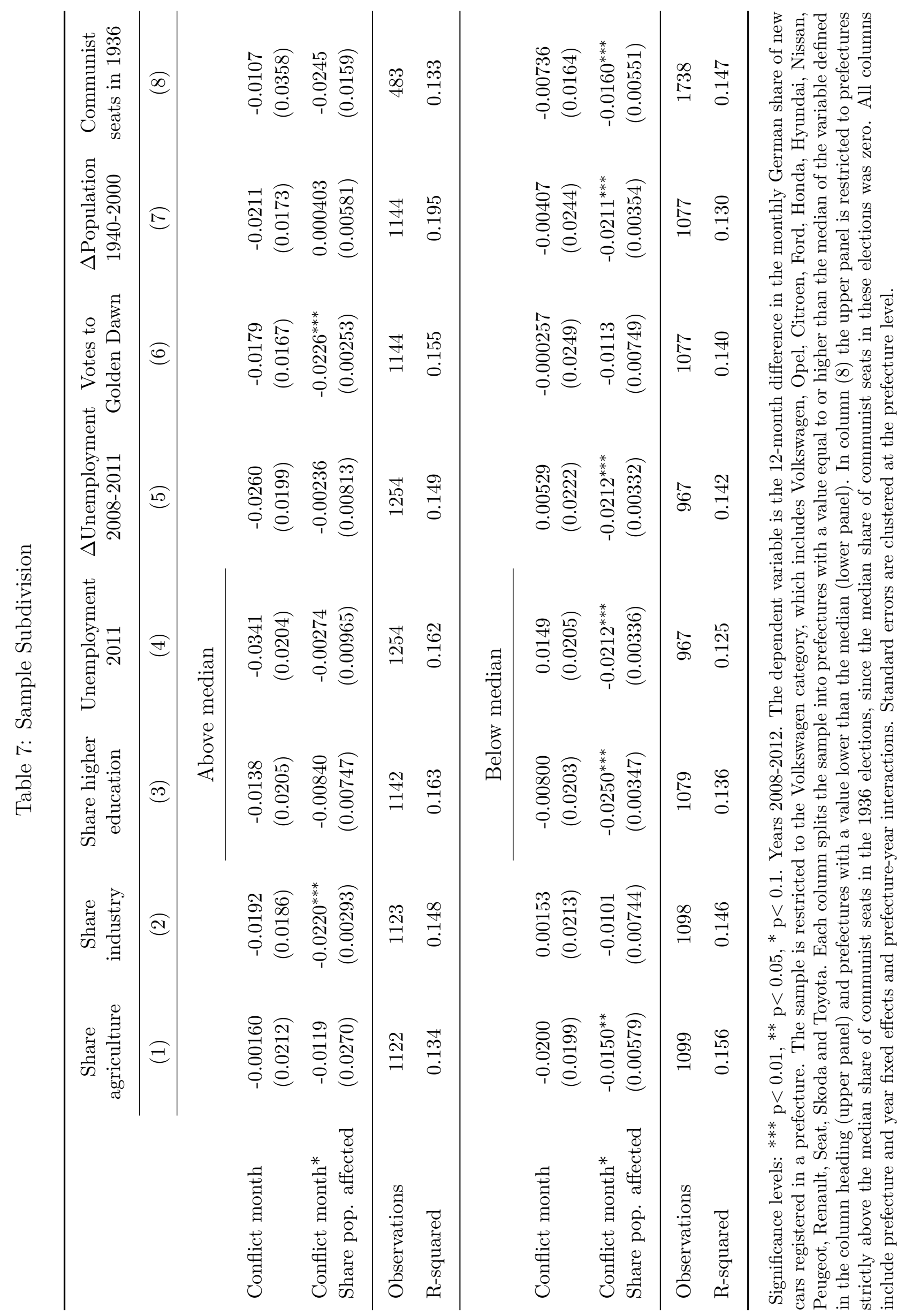


Table 8: Alternative Measures of German-Greek Conflict

\begin{tabular}{lcccccc}
\hline & $(1)$ & $(2)$ & $(3)$ & $(4)$ & $(5)$ & $(6)$ \\
\hline Share pop. affected & $0.00415^{* *}$ & $0.00520^{* *}$ & & $0.00296^{*}$ & $0.00345^{* *}$ & \\
& $(0.00195)$ & $(0.00212)$ & & $(0.00150)$ & $(0.00162)$ & \\
Share articles & $-0.461^{*}$ & -1.096 & -1.537 & & & \\
& $(0.230)$ & $(4.388)$ & $(6.769)$ & & & \\
Share articles* & $-0.0974^{* * *}$ & $-0.120^{* *}$ & -0.0843 & & & \\
Share pop. affected & $(0.0281)$ & $(0.0476)$ & $(0.102)$ & & & \\
Google Index & & & & 0.000778 & 0.00457 & 0.0113 \\
& & & & $(0.00105)$ & $(0.0197)$ & $(0.0207)$ \\
Google Index* & & & & $-0.000745^{* * *}$ & $-0.000858^{* * *}$ & $-0.00119^{*}$ \\
Share pop. affected & & & & $(0.000152)$ & $(0.000293)$ & $(0.000641)$ \\
\hline Observations & 2221 & 2221 & 2221 & 2221 & 2221 & 2221 \\
R-squared & 0.0406 & 0.0437 & 0.147 & 0.0387 & 0.0413 & 0.146 \\
\hline Controls & Yes & Yes & No & Yes & Yes & No \\
Prefecture $\times$ Year & No & No & Yes & No & No & Yes \\
Controls $\times$ & No & Yes & Yes & No & Yes & Yes \\
conflict month & & & & & & \\
\hline
\end{tabular}

Significance levels: ${ }^{* * *} \mathrm{p}<0.01,{ }^{* *} \mathrm{p}<0.05,{ }^{*} \mathrm{p}<0.1$. Years 2008-2012. The dependent variable is the 12 -month difference in the monthly German share of new cars registered in a prefecture. The variable Share articles is the monthly share of Kathimerini articles related to German-Greek conflict. The variable Google Index is the average growth rate in the Google Trends search index for the terms "Germans", "German reparations" and "Distomo". The sample is restricted to the Volkswagen category, which includes Volkswagen, Opel, Citroen, Ford, Honda, Hyundai, Nissan, Peugeot, Renault, Seat, Skoda and Toyota. Prefecture controls include $\log$ (population) in 2001, share employed in agriculture in 2001, share employed in industry in 2001, share with higher education in 2001, share with secondary education in 2001, unemployment rate in 2001, ruggedness, average distance from the nearest road in 1940 and average distance from the nearest railway line in 1940. Standard errors are clustered at the prefecture level. 


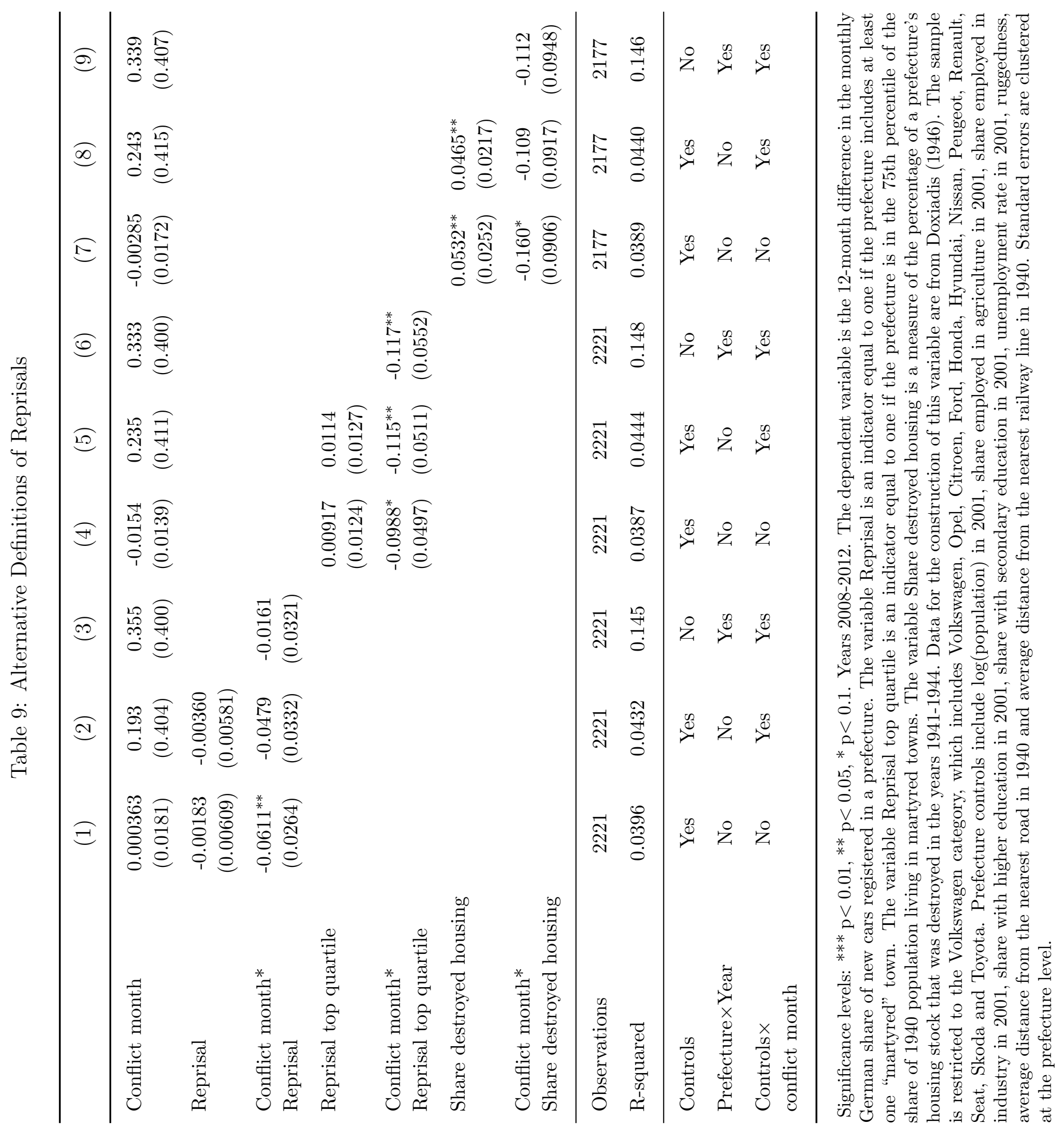


Table 10: Assessing Selection on Unobservables

\begin{tabular}{llcc}
\hline Controls restricted & Controls full & \multicolumn{2}{c}{ Sample } \\
& & All brands & VW Category \\
\hline None & $\begin{array}{l}\text { Baseline prefecture-level controls from Ta- } \\
\text { ble 6, Column (4) }\end{array}$ & -19.6 & -13.5 \\
None & $\begin{array}{l}\text { Baseline prefecture-level controls and inter- } \\
\text { actions of controls with the conflict month }\end{array}$ & -9.8 & -6.7 \\
\hline
\end{tabular}

The table reports the relative strength of unobservables needed to completely explain away the effect of a conflict month on the difference of the seasonally adjusted German car share between reprisal and non-reprisal prefectures (Altonji et al., 2005). Both restricted and unrestricted regressions include year fixed effects. 
Table 11: Effects by Membership in Facebook Boycott Groups

\begin{tabular}{|c|c|c|c|c|c|c|}
\hline & \multicolumn{3}{|c|}{ Below median } & \multicolumn{3}{|c|}{ Above median } \\
\hline & (1) & $(2)$ & (3) & (4) & (5) & (6) \\
\hline Share pop. affected & $\begin{array}{l}-0.00450 \\
(0.00486)\end{array}$ & & & $\begin{array}{c}0.00346^{*} \\
(0.00183)\end{array}$ & & \\
\hline Conflict month & $\begin{array}{c}0.000600 \\
(0.0276)\end{array}$ & $\begin{array}{c}0.480 \\
(0.783)\end{array}$ & $\begin{array}{c}1.628^{*} \\
(0.829)\end{array}$ & $\begin{array}{l}-0.0115 \\
(0.0166)\end{array}$ & $\begin{array}{c}0.220 \\
(0.487)\end{array}$ & $\begin{array}{c}0.165 \\
(0.416)\end{array}$ \\
\hline $\begin{array}{l}\text { Conflict month* } \\
\text { Share pop. affected }\end{array}$ & $\begin{array}{l}-0.0176 \\
(0.0222)\end{array}$ & $\begin{array}{r}-0.00908 \\
(0.0303)\end{array}$ & $\begin{array}{c}0.0320 \\
(0.0352)\end{array}$ & $\begin{array}{r}-0.0179^{* * *} \\
(0.00482)\end{array}$ & $\begin{array}{c}-0.00969^{* * *} \\
(0.00320)\end{array}$ & $\begin{array}{l}-0.00969^{*} \\
(0.00512)\end{array}$ \\
\hline Observations & 1127 & 1127 & 1127 & 1094 & 1094 & 1094 \\
\hline R-squared & 0.0614 & 0.0763 & 0.165 & 0.0395 & 0.0459 & 0.143 \\
\hline Controls & Yes & Yes & No & Yes & Yes & No \\
\hline Prefecture $\times$ Year & No & No & Yes & No & No & Yes \\
\hline $\begin{array}{l}\text { Controls } \times \\
\text { conflict month }\end{array}$ & No & Yes & Yes & No & Yes & Yes \\
\hline
\end{tabular}

Significance levels: $* * * \mathrm{p}<0.01,{ }^{* *} \mathrm{p}<0.05,{ }^{*} \mathrm{p}<0.1$. Years 2008-2012. The dependent variable is the 12-month difference in the monthly German share of new cars registered in a prefecture. The sample is divided into prefectures with above and below median membership in Facebook groups that call for the boycott of German products. The number of members is computed based on the entry in the field "Current City" in a user's Facebook profile and is normalized by the prefecture population. The sample is restricted to the Volkswagen category, which includes Volkswagen, Opel, Citroen, Ford, Honda, Hyundai, Nissan, Peugeot, Renault, Seat, Skoda and Toyota. Prefecture controls include $\log$ (population) in 2001, share employed in agriculture in 2001, share employed in industry in 2001, share with higher education in 2001, share with secondary education in 2001, unemployment rate in 2001, ruggedness, average distance from the nearest road in 1940 and average distance from the nearest railway line in 1940. Standard errors are clustered at the prefecture level. 


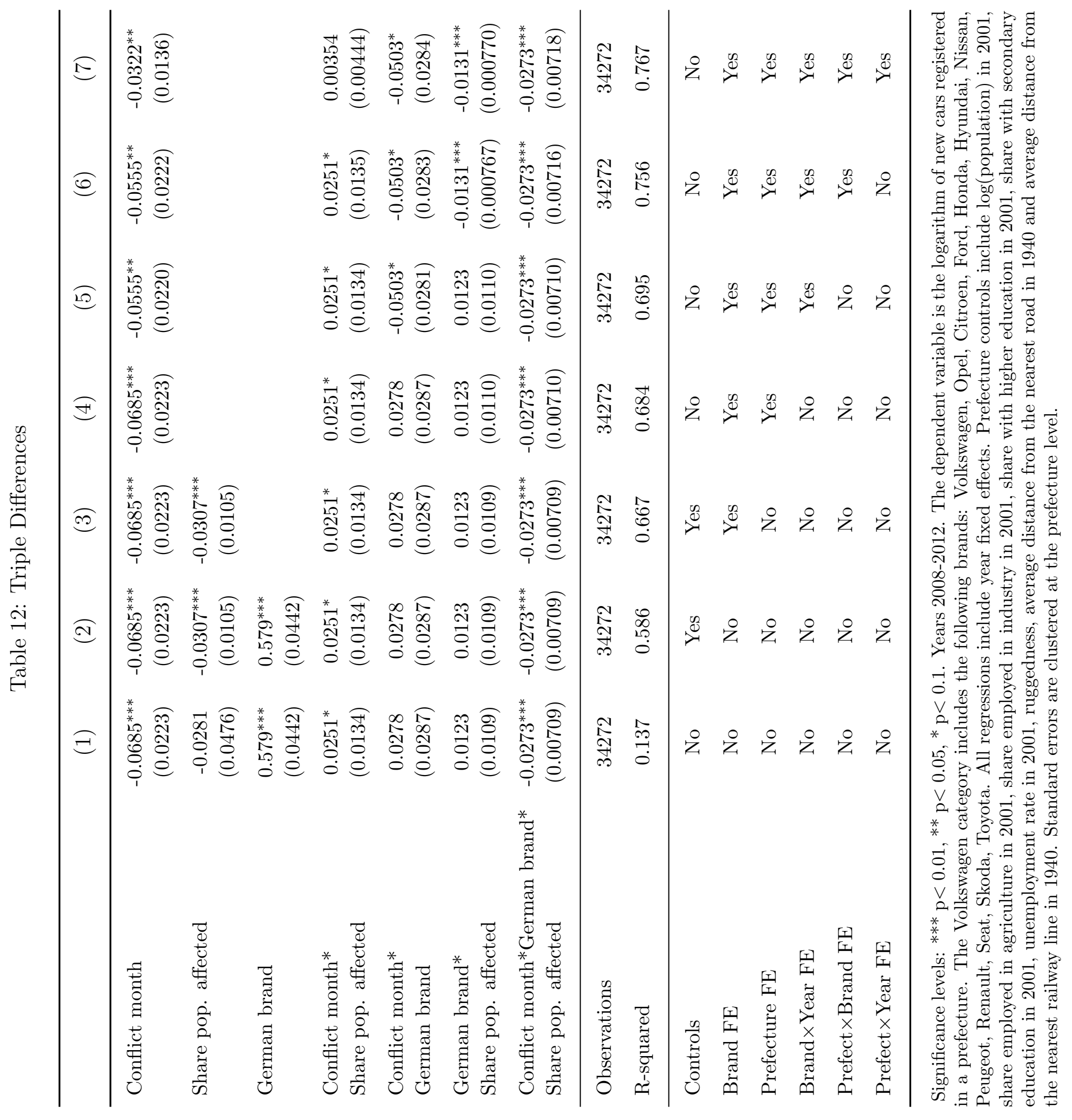




\section{B Data Appendix}

\section{B.1 Variable descriptions}

\begin{tabular}{|c|c|}
\hline Variable & Description and Source \\
\hline German car share & $\begin{array}{l}\text { The monthly share of German-manufactured cars in a pre- } \\
\text { fecture's total new car registrations, expressed as the differ- } \\
\text { ence of the share in month t from month t- } 12 \text {. Manufactur- } \\
\text { ers defined as German are Volkswagen, Opel, BMW, Audi, } \\
\text { Porsche, Mercedes and Smart. }\end{array}$ \\
\hline Conflict month & $\begin{array}{l}\text { Defined as a local peak in the growth series of the monthly } \\
\text { share of Kathimerini articles relevant to German-Greek } \\
\text { conflict, and the month after the peak. For details on } \\
\text { the selection of the relevant articles see Appendix C. } \\
\text { Source: Kathimerini electronic archive 2008-2012, sections } \\
\text { on "Greece", "Politics" and "Economy". }\end{array}$ \\
\hline Share pop. affected & $\begin{array}{l}\text { The share of a prefecture's } 1940 \text { population that lived in } \\
\text { towns designated as "martyred towns" by Presidential De- } \\
\text { crees no. } 399(1998), 99(2000), 40(2004) \text { and } 140 \text { (2005). } \\
\text { Population data are from the } 1940 \text { Greek census. }\end{array}$ \\
\hline Share destroyed housing & $\begin{array}{l}\text { The share of a prefecture's pre-war housing stock that was } \\
\text { destroyed in the period 1941-1944. Source: Doxiadis (1947). }\end{array}$ \\
\hline Share articles & $\begin{array}{l}\text { Monthly Kathimerini articles relevant to German-Greek } \\
\text { conflict, normalized by the total number of Kathimerini ar- } \\
\text { ticles in the month. For details on the selection of the rel- } \\
\text { evant articles see Appendix C. Source: Kathimerini elec- } \\
\text { tronic archive 2008-2012, sections on "Greece", "Politics" } \\
\text { and "Economy". }\end{array}$ \\
\hline Google Index & $\begin{array}{l}\text { Average growth rate of the monthly Google search index } \\
\text { series for the terms "Germans", "German reparations" and } \\
\text { "Distomo" in the period 2008-2012, for the geographic area } \\
\text { of Greece. The Google search index is a normalization of the } \\
\text { share of total searches represented by each term in a given } \\
\text { time and region. }\end{array}$ \\
\hline Facebook membership & $\begin{array}{l}\text { Number of members in Facebook groups that call for the } \\
\text { boycott of German or foreign products, normalized by the } \\
\text { prefecture's population in } 2001 \text {. Members' location is their } \\
\text { current location and not their place of origin. }\end{array}$ \\
\hline Population & Source: 2001 Greek census. \\
\hline Share employed in agriculture & Source: 2001 Greek census. \\
\hline
\end{tabular}


Share employed in industry

Share with secondary

education

Share with higher education

Share civil servants

Unemployment rate

Share seats to communists

Votes to Golden Dawn

Ruggedness

Average distance to nearest road in 1940

Average distance to nearest railway line in 1940
Source: 2001 Greek census.

Source: 2001 Greek census.

Source: 2001 Greek census.

Source: 2001 Greek census.

Source: 2001 Greek census.

The share of a prefecture's seats allocated to the coalition of the Greek Communist Party and the Greek Agrarian Party (Pallaiko Metopo) in the 1936 parliamentary elections. Source: Hellenic Parliament, Registry of Parliament Members.

The share of a prefecture's votes to the party of Golden Dawn in the June 2012 parliamentary elections. Source: Hellenic Ministry of Interior.

Terrain ruggedness index computed as in Riley et al. (1999) and averaged over each prefecture's surface. The shapefile of prefecture boundaries is from Hel.Stat. and elevation data from GMTED2010.

To compute this measure we first compute the distance to the nearest road from the centroid of each $50 \times 50 \mathrm{~km}$ grid cell in an equidistant projection and then average over each prefecture's surface. We digitize a physical map of Greece's pre-WWII road network from Doxiadis (1947). The shapefile of prefecture boundaries is from Hel.Stat.

Similarly to the above measure, we first compute the distance to the nearest railway line from the centroid of each $50 \times 50 \mathrm{~km}$ grid cell in an equidistant projection and then average over each prefecture's surface. We digitize a physical map of Greece's pre-WWII railway network from Doxiadis (1947). The shapefile of prefecture boundaries is from Hel.Stat.

\section{B.2 List of martyred towns}

1. Aetos, Messinia

2. Agia Efthimia, Fokida

3. Agii Anargiri, Lakonia

4. Agios Vassilios, Iraklio
5. Amira, Iraklio

6. Ano Meros, Rethymno

7. Ano Viannos, Iraklio

8. Anogia, Rethymno
9. Arginia, Kefallonia

10. Asprageloi, Ioannina

11. Chondros, Iraklio

12. Chortiatis, Thessaloniki 

13. Damasta, Iraklio
33. Kefalovryso, Iraklio
53. Pentapoli, Fokida
14. Distomo, Viotia
34. Klisoura, Kastoria
54. Pirgi, Kozani
15. Drakia, Magnisia
35. Kommeno, Arta
55. Prosilio, Fokida
16. Drosopigi, Florina
36. Koxare, Rethymno
56. Pteri, Achaia
17. Elati, Ioannina
37. Kria Vrissi, Rethymno
57. Riza, Lasithi
18. Emparos, Iraklio
38. Lechovo, Florina
58. Rizomilo, Magnisia
19. Eptalofos, Fokida
39. Lidoriki, Fokida
59. Rodakinou, Rethymno
20. Erimanthia, Achaia
40. Ligiades, Ioannina
60. Rogi, Achaia
21. Gdochia, Lasithi
41. Lilea, Fokida
61. Saktouria, Rethymno
22. Gerakari, Rethymno
42. Lochria, Rethymno
62. Sarchos, Iraklio
23. Ipati, Fthiotida
43. Magarikari, Iraklio
63. Sidironero, Drama
24. Kakopetro, Chania
44. Malathiros, Chania
64. Sikologos, Iraklio
25. Kalami, Iraklio
45. Manassis, Ioannina
65. Skines, Chania
26. Kalavryta, Achaia
46. Mesovouni, Ioannina
66. Sougia, Chania
27. Kaloskopi, Fokida
47. Mesovouno, Kozani
67. Tibaki, Iraklio
28. Kaloutas, Ioannina
48. Mirtos, Lasithi
68. Vachos, Iraklio
29. Kandanos, Chania
49. Mournies, Lasithi
69. Vlacherna, Arkadia
30. Karoutes, Fokida
50. Mousiotitsa, Ioannina
70. Vorizia, Iraklio
31. Kato Simi, Iraklio
51. Nea Kerdillia, Serres
71. Vounichora, Fokida
32. Kato Viannos, Iraklio
52. Pefko, Iraklio
72. Vrisses, Rethymno

\section{B.3 News Index Construction}

For the construction of the index, we use the full 2008-2012 Kathimerini archive of the sections "Greece", "Politics" and "Economy", containing a total of 64,854 articles. As a first step, we sample $10 \%$ of articles containing the stem "german-" and manually classify them into relevant and non-relevant to political tension between Germany and Greece. An article classified as relevant must contain a reference, however short, to German-Greek conflicting political interests or political interactions in the context of foreign relations, the eurozone or the issue of German war reparations. Articles that refer to German-Greek relations in another context - e.g. tourism flows, economic 
transactions between German and Greek firms etc. - are classified as non-relevant.

We split the audited sample into a training and test set and use the test set to evaluate the classification performance of our algorithm. We start by assigning a frequency score to each term appearing more than three times in the articles of the training set. This score captures how frequently the term appears in conflict-related articles relative to non-conflict-related articles. The frequency score for term i is an empirical index constructed as:

$$
\text { Frequency score }{ }_{i}=\frac{\operatorname{Pr}(\mathrm{i} \mid \mathrm{c})}{\operatorname{Pr}(\mathrm{i} \mid \mathrm{c})+\operatorname{Pr}(\mathrm{i} \mid \mathrm{nc})} * 100
$$

where $\mathrm{c}$ is a conflict-related article and nc an unrelated article. The score takes on the value 100 when a term appears only in conflict-related articles and the value 0 when it appears only in unrelated articles. Terms like bankruptcy, memorandum, austerity, but also subtler terms like discipline, painful, tolerance, score above 95 in this index.

We use the list of high-scoring terms and form all combinations of 5 or more terms from this list. For each combination, we classify an article in our test set as conflictrelated if it contains at least one of the terms in the combination. We then compare this classification to the human audit and evaluate each combination of terms based on a compound measure of precision and recall known as the F1-score. Since we are interested in minimizing both false positive and false negative classifications of articles, we put equal weight on the two types of errors and pick the combination that maximizes:

$$
F_{1}=2 * \frac{2 * \text { true positive }}{2 * \text { true positive }+ \text { false negative }+ \text { false positive }}
$$

Based on the above procedure, we end up classifying an article as related to GermanGreek conflict if it contains the stem "german-" and at least one of the words in the set $\{$ memorandum, troika, haircut, Distomo, default, austerity, Schaeuble $\}$. This gives us a monthly count of conflict-related articles, which we normalize by the total number 
of articles Kathimerini published in the month.

\section{Additional Tables and Figures}

Figure C.1 looks at the seasonally adjusted change in the market share of German cars by prefecture. Bars in dark blue indicate that a massacre was carried out by the German forces after 1941. All five prefectures with the largest declines in the share of German cars were also the site of German massacres. The prefecture of Fokida, for example, home to the martyred town of Distomo, saw almost 12 percent of its 1940 population killed or made homeless by German retribution measures. During periods of German-Greek conflict in the period 2008-2012, the German market share dropped by almost 20 percentage points (and close to 30 percentage points in the Volkswagen category) 21

\footnotetext{
${ }^{21}$ Rethymno, a prefecture on Crete, saw massive German reprisals after the capture of the island. In one famous incident, German parachute regiments perpetrated the so-called "Holocaust of Kedros" - a pre-emptive strike against partisan forces, with 8 villages burnt to the ground and all male inhabitants (164 men and boys) shot (Nessou, 2009). Rethymno registered the second-largest decline in the share of German cars in our sample - some 14\%. Third on the list is the prefecture of Arta, site of the massacre of Kommeno, with 317 civilian victims (Mazower, 1995). It shows a drop of 13 percentage points in the share of German cars in conflict months (14 for the VW category). In contrast, the neighboring prefecture of Preveza - not affected by German reprisals - experienced a drop of only 3 percent.
} 
Figure C.1: Decline in the Market Share of German Cars

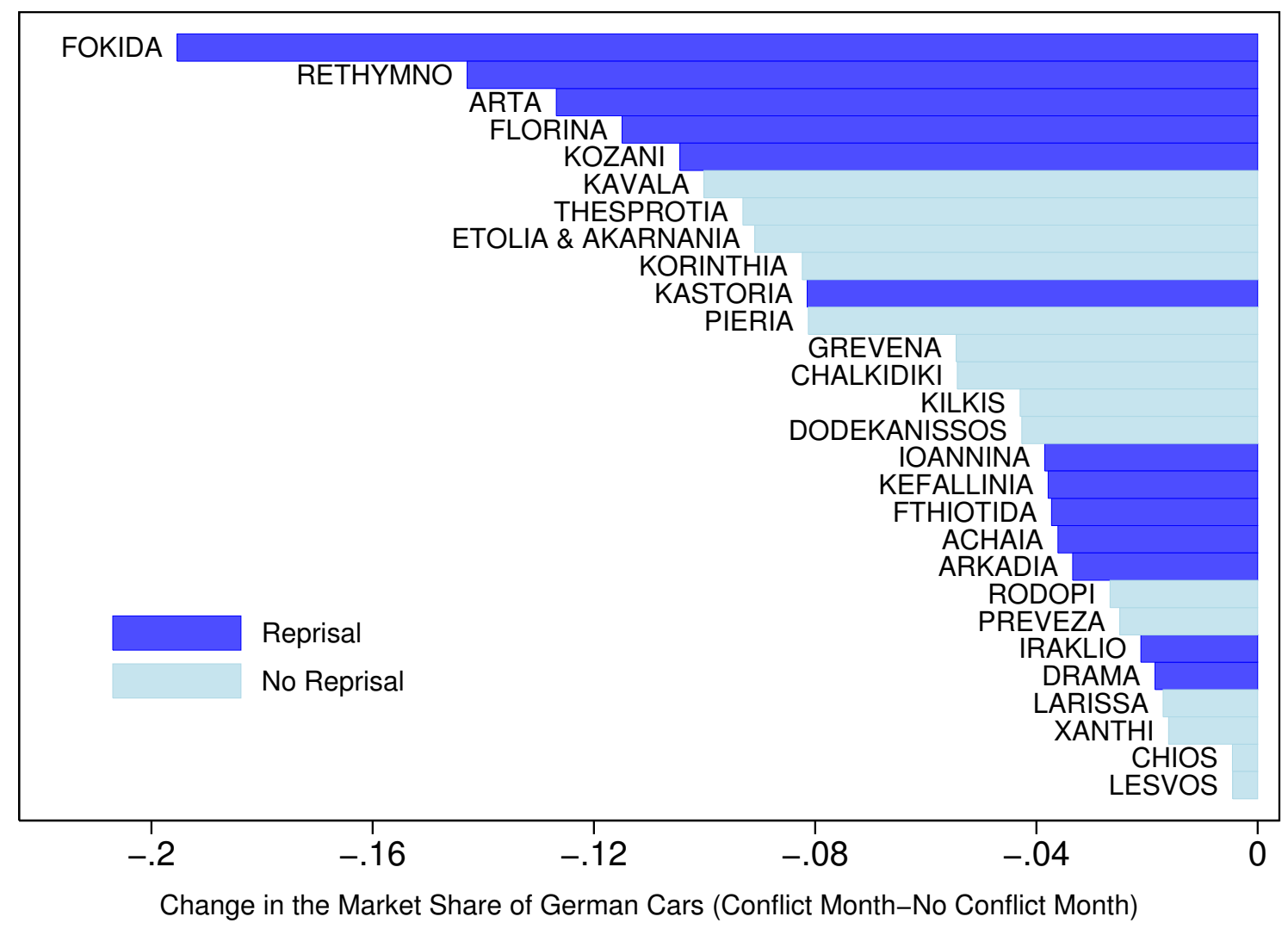

Notes: The figure shows the seasonally adjusted change in the market share of German cars during coflict months. We adjust seasonally by examining the difference in market share between month $t$ and $\mathrm{t}-12$. 